


\section{USER GUIDE \\ FOR PREQUALIFICATION \\ OF BIDDERS \\ STANDARD BIDDING DOCUMENT}

DECEMBER 2021

For projects governed by Procurement Regulations for ADB Borrowers:

Goods, Works, Nonconsulting and Consulting Services (2017) 


\section{(C) $\$($ Creative Commons Attribution-NonCommercial-NoDerivs 3.0 IGO license BY NC ND (CC BY-NC-ND 3.0 IGO)}

(c) 2021 Asian Development Bank 6 ADB Avenue, Mandaluyong City, 1550 Metro Manila, Philippines

Tel +632 8632 4444; Fax +63286362444

www.adb.org

Some rights reserved. Published in 2021.

ISBN 978-92-9269-296-4 (print); 978-92-9269-297-1 (electronic)

Publication Stock No. TIM210541-2

DOI: http://dx.doi.org/10.22617/TIM210541-2

The views expressed in this publication are those of the authors and do not necessarily reflect the views and policies of the Asian Development Bank (ADB) or its Board of Governors or the governments they represent.

ADB does not guarantee the accuracy of the data included in this publication and accepts no responsibility for any consequence of their use. The mention of specific companies or products of manufacturers does not imply that they are endorsed or recommended by ADB in preference to others of a similar nature that are not mentioned.

By making any designation of or reference to a particular territory or geographic area, or by using the term "country" in this document, $A D B$ does not intend to make any judgments as to the legal or other status of any territory or area.

This work is available under the Creative Commons Attribution-NonCommercial-NoDerivs 3.0 IGO license (CC BY-NC-ND 3.0 IGO) http://creativecommons.org/licenses/by-nc-nd/3.0/igo/. By using the content of this publication, you agree to be bound by the terms of this license. For attribution and permissions, please read the provisions and terms of use at https://www.adb.org/terms-use\#openaccess.

This CC license does not apply to non-ADB copyright materials in this publication. If the material is attributed to another source, please contact the copyright owner or publisher of that source for permission to reproduce it. ADB cannot be held liable for any claims that arise as a result of your use of the material.

Please contact pubsmarketing@adb.org if you have questions or comments with respect to content, or if you wish to obtain copyright permission for your intended use that does not fall within these terms, or for permission to use the ADB logo.

Corrigenda to ADB publications may be found at http://www.adb.org/publications/corrigenda.

Notes:

In this document, "\$” refers to United States dollars.

This document applies to projects governed by the Procurement Regulations for ADB Borrowers: Goods, Works, Nonconsulting and Consulting Services (2017, as amended from time to time). 


\section{Contents}

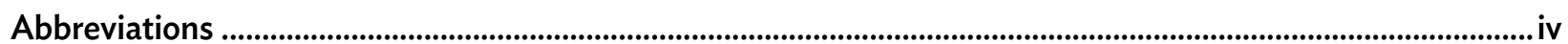

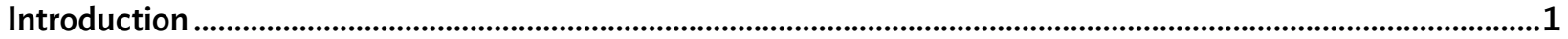

The Prequalification Process ..................................................................................................................................2

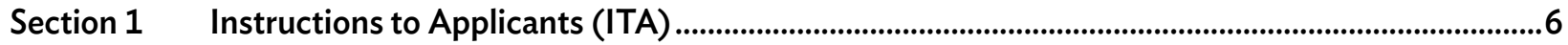

This section specifies the procedures Applicants should follow when preparing and submitting their applications.

Information is also provided on opening and evaluation of applications.

\section{Section 2 Application Data Sheet (ADS)}

This section consists of provisions that are specific to each prequalification and supplement the information or requirements included in Section 1 (Instructions to Applicants).

\section{Section 3 Qualification Criteria (QLC)}

This section contains the criteria and methods to be used to evaluate Applications.

\section{Section 4 Application Forms (APF)}

This section contains the Application Submission Sheet and all the forms required to be submitted with the Application.

Section 5 Eligible Countries (ELC)

This section contains the list of eligible countries.

\section{Section 6 Scope of Contract (SOC)}

This section includes a summary description of the scope of contract and additional information on major contract components, major quantities, required construction methods, the key personnel and key equipment requirements, and the contract implementation period of the Contract subject of this prequalification exercise.

Glossary 


\title{
Abbreviations
}

\author{
ADB.........................Asian Development Bank \\ ADS ........................application data sheet \\ APF........................application forms \\ CON ......................historical contract nonperformance \\ ELC .........................eligible countries \\ ELI..........................eligibility form \\ EXP.........................experience form \\ FIN..........................financial data form \\ IFP..........................invitation for prequalification \\ ITA ..........................instructions to applicants \\ OCB .......................open competitive bidding \\ QLC.........................qualification criteria \\ SOC .........................scope of contract \\ SPQD ......................standard procurement document for the prequalification of bidders
}




\section{Introduction}

This Standard Procurement Document for the Prequalification of Bidders (SPQD) of the Asian Development Bank $(A D B)$ has been prepared by $A D B$ to facilitate prequalification of Bidders for contracts to be procured through open competitive bidding. The SPQD is based on the master procurement document entitled "Prequalification Documents for Procurement of Works," which was prepared by multilateral development banks and other public international financial institutions, and reflects the majority view of these institutions. The SPQD has the structure and the provisions of the master procurement document, except where ADB-specific considerations have required a change.

The Procurement Regulations for ADB Borrowers: Goods, Works, Nonconsulting and Consulting Services (2017, as amended from time to time) generally recommends the use of prequalification for large or complex works, contracts for technically complex plant, ${ }^{1}$ or any other circumstances in which the high costs of preparing detailed bids could discourage competition. ${ }^{2}$ The successful execution of these large and complex projects requires that contracts are awarded only to firms, or combinations of firms, which are suitably experienced in the type of work and construction technology involved, and that are financially and managerially sound. The assessment by the Employer of the suitability of firms to carry out a particular contract prior to being invited to submit a bid is a process called prequalification. Prequalification is followed by a closed competitive bidding procedure in which only those firms meeting specified prequalification criteria are invited to submit a bid. All Applicants meeting the specified criteria shall be allowed to bid.

The SPQD has been prepared to ensure that only firms with appropriate experience, a proven track record, and adequate annual turnover, but without a significant history of contract nonperformance, will be invited to submit bids. An important feature of the SPQD is that it can be used with minimum changes, as it does not contain explanations, footnotes, or examples. The SPQD is only available in electronic format.

The purpose of this User's Guide is to provide guidance to employers on how to prepare a prequalification document based on the SPQD and how to evaluate applications for (i) large and complex civil works contract and (ii) contracts for technically complex plant. This guide includes an initial section on how to prepare the Invitation for Prequalification. The Employer should note that the Invitation for Prequalification is not a part of the prequalification document.

ADB welcomes any feedback or experiences from both borrowers and Bidders on the use of its SPQD. For information on procurement under ADB-financed projects, contact

Procurement, Portfolio and Financial Management Department (PPFD)

Asian Development Bank

6 ADB Avenue, Mandaluyong City

1550 Metro Manila, Philippines

E-mail: procurement@adb.org

Tel: +63286324444

Fax: +63286362444 [Attn: Director General, PPFD]

www.adb.org

1 These may include large and complex buildings, civil engineering structures, design, and build or supply and installation projects.

2 See para. 14 of Appendix 3: Open Competitive Bidding. 


\section{The Prequalification Process}

\section{Advertisement and Notification}

The Invitation for Prequalification (IFP) shall be advertised on the Asian Development Bank (ADB) website; on a freely and publicly accessible website in English; and in a newspaper of national circulation (at least in one English language newspaper, if available) or website in the borrower's country. A copy of the IFP shall be submitted to ADB for no-objection and for publication on the ADB website in accordance with the Procurement Regulations for ADB Borrowers: Goods, Works, Nonconsulting and Consulting Services (2017, as amended from time to time).

ADB may additionally require that the IFP be advertised in well-known technical magazines or trade publications, or in newspapers of wide international circulation, in sufficient time to enable prospective Bidders to prepare and submit applications.

\section{Preparing and Issuing a Prequalification Document}

The Employer and Applicants should keep in mind the following:

- The Employer is responsible for preparing and issuing the prequalification document.

- Where prequalification is required, the Employer shall use ADB's Standard Procurement Document for the Prequalification of Bidders (SPQD), as this is a mandatory requirement for contracts to be financed by ADB and procured under open competitive bidding. ${ }^{1}$

- The Employer shall prepare the prequalification document using the published version of the SPQD without suppressing or adding text to Section 1 (Instructions to Applicants) (ITA). All information and data particular to each individual prequalification process must be provided by the Employer in the following sections of the prequalification document:

Section 2 (Application Data Sheet)

Section 3 (Qualification Criteria)

Section 4 (Application Forms)

Section 5 (Eligible Countries)

Section 6 (Scope of Contract)

- The Employer shall allow Applicants sufficient time, depending on the magnitude and complexity of the contract, but generally not less than 42 days to

- study the prequalification document,

- prepare complete and responsive applications, and

- submit their applications.

1

For other types of procurement where no relevant SPQD has been issued by ADB, the Employer may use other internationally or nationally recognized documents provided that they are consistent with the Procurement Regulations and acceptable to ADB. 


\section{Preparation and Submission of Applications}

The Applicant is solely responsible for the preparation and submission of its application. During this stage, the Employer shall

- promptly respond to requests for clarifications from applicants and amend, as needed, the prequalification document; and

- amend the prequalification document only with the prior approval of ADB.

\section{Opening and Evaluation of Applications}

The Employer is responsible for the opening and evaluation of applications, which is a critical event in the prequalification process. The Employer shall appoint experienced staff to conduct the evaluation of applications. Mistakes committed at evaluation may later prompt complaints from Applicants, requiring reevaluation of the applications, with consequent delays and waste of resources.

The Employer, in observance of best practices, shall

- maintain strict confidentiality throughout the evaluation process;

- reject any attempts or pressures to distort the outcome of the evaluation, including fraud and corruption;

- strictly apply only and all of the qualification criteria specified in the prequalification document; and

- notify all applicants in writing of the names of those applicants who have been prequalified.

\section{Updating and Confirmation of Bidder's Qualifications}

Information pertaining to a bidder's eligibility, historical contract nonperformance, and financial situation shall be updated during bidding.

Additional qualifying requirements not examined during prequalification such as

- financial resources and current contract commitments,

- equipment to be allocated for the particular contract, and

- personnel to be fielded for the particular contract

shall be included in the bidding document and will be assessed during bid evaluation.

\section{Use of Electronic Procurement System}

When an electronic procurement system is used, the applicable procedures of the prequalification process such as for (i) advertisement and notification; (ii) preparing and issuing a Prequalification Document; (iii) preparing and submission of applications; (iv) application opening and evaluation of applications; and (v) updating and confirmations of Bidder's qualification, including the means of communication between the Employer and Applicants, shall be specified in the relevant clauses of Section 2 (Application Data Sheet). 


\title{
Invitation for Prequalification
}

\author{
[Letterhead of the Employer]
}

Date

Loan/Grant No. and Title

Contract No(s). and Title(s)

Deadline for Submission of Application ...... [insert closing date and time].......

1. The [insert name of the borrower or recipient] has received ${ }^{1}$ financing from the ADB toward the cost of [insert name of the project]. Part of this financing will be used for payments under the Contract named above. [insert if applicable: "This contract will be jointly financed by [insert name of the cofinancing agency]. The eligibility rules and procedures of ADB will govern the prequalification and the bidding process."]

2. The [insert name of the Employer] (the "Employer") intends to prequalify firms for: [insert general description of the scope of the contract]. ${ }^{2}$

3. Only eligible Applicants with the following key qualifications ${ }^{3}$ defined in the Prequalification Document may participate in this prequalification:

4. It is expected that the Invitation for Bids will be made in [insert month and year].

5. To obtain further information and inspect the Prequalification Document, interested eligible Applicants should contact:

[insert employer's office $]^{4}$

[insert name of the officer]

[insert postal address or street address, include zip code]

[insert telephone number including country code]

[insert e-mail address]

[insertfax number]

6. To purchase the Prequalification Document, eligible Applicants should

- write to address above requesting the Prequalification Document for [insert number and title of the contract] and

- pay a nonrefundable fee ${ }^{5}$ of [insert amount and currency] by [insert method of payment $]^{6}$

The document will be sent by [insert delivery procedure $].{ }^{7}$ No liability will be accepted for loss or late delivery.

Substitute with "has applied for" or "intends to apply for" if appropriate.

Where prequalification is called for multiple contracts, substitute "contract" in para. 1 with "contracts" and provide descriptions for all the contracts in para 2.

Insert an additional paragraph indicating key qualification criteria consistent with the prequalification document to enable potential Applicants to decide whether to respond to the invitation.

4 The Borrower and the Employer may be the same or different entities. The text of the Invitation for Prequalification and the texts of the other associated documents must indicate which agency will act as the Employer.

5 The fee, to defray printing and mailing or shipping costs, should be nominal.

6 For example, cashier's check, direct deposit to a specified account number, etc.

7 The delivery procedure is usually airmail for overseas delivery and surface mail or courier for local delivery. If urgency or security dictates, courier services may be required for overseas delivery. 
7. Deliver your Application:

- to the address [insert address]

- on or before [insert closing date and time consistent with the Application Data Sheet]. ${ }^{8}$

The Employer reserves the right to accept or reject late Applications.

8. The Employer will not be responsible for any costs or expenses incurred by Applicants in connection with the preparation or delivery of their Applications.

9. The Employer will notify all Applicants in writing of the names of those Applicants who have been prequalified.

8 Depending on the magnitude and complexity of the contract, the duration may vary, but generally a minimum period of 6 weeks should be allowed for the submission of prequalification applications. This period is counted from either (i) the issuance or the publication date of the Invitation for Prequalification; or (ii) the date of availability of the prequalification documents, whichever is later, to the date for submission of prequalification applications. 


\section{Section 1: Instructions to Applicants}

This Section 1 (Instructions to Applicants) (ITA) specifies the procedures that regulate the prequalification process. The ITA contain standard provisions that have been designed to remain unchanged and to be used without modifying their text. Information is also provided on the submission, opening, and evaluation of applications. The ITA clearly identify the information that may need to be specified by the Employer for the prequalification process and require that such information be introduced through Section 2 (Application Data Sheet).

\section{Table of Clauses}

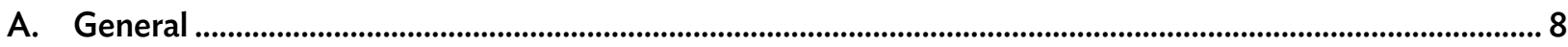

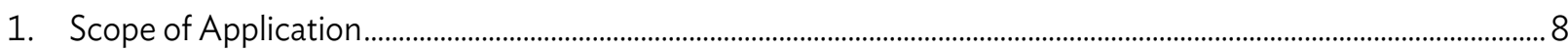

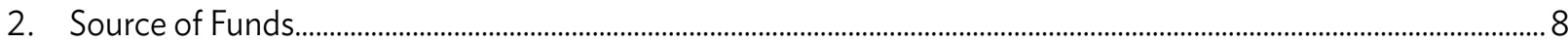

3. Fraud and Corruption .................................................................................................................................................

4. Eligible Applicants............................................................................................................................................................... 11

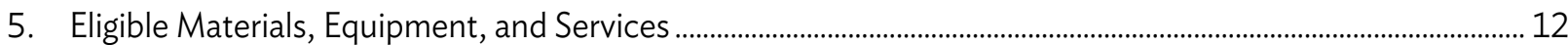

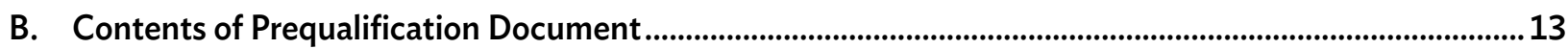

6. Sections of the Prequalification Document .......................................................................................................... 13

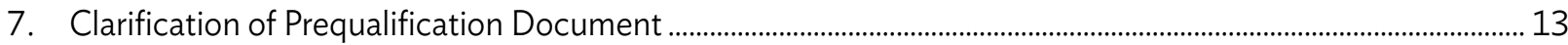

8. Amendment of Prequalification Document ........................................................................................................... 14

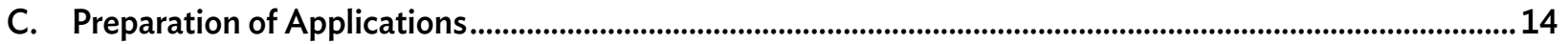

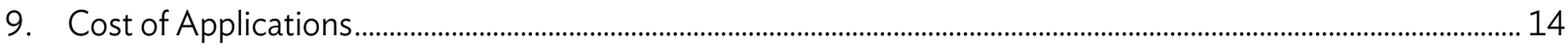

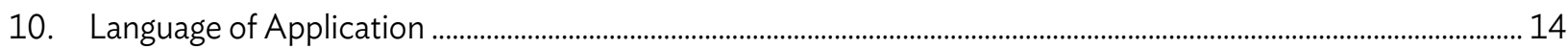

11. Documents Comprising the Application .................................................................................................................. 14

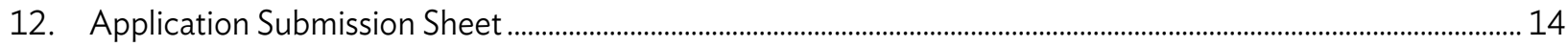

13. Documents Establishing the Eligibility of the Applicant ...................................................................................... 15

14. Documents Establishing the Qualifications of the Applicant................................................................................... 15

15. Format and Signing of the Application ……………………............................................................................................ 15 


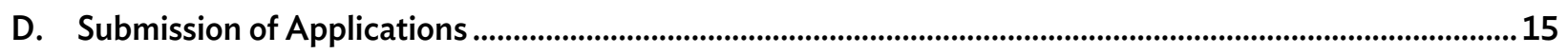

16. Sealing and Marking of Applications ………………………............................................................................................ 15

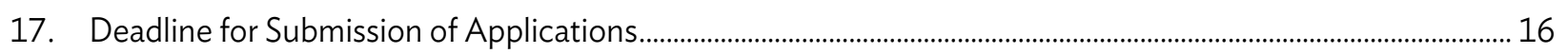

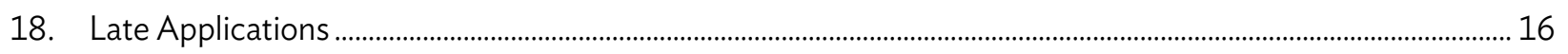

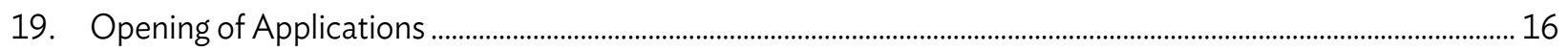

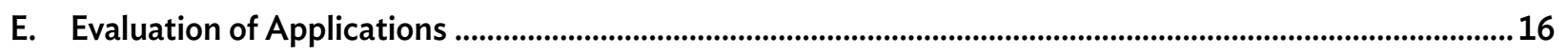

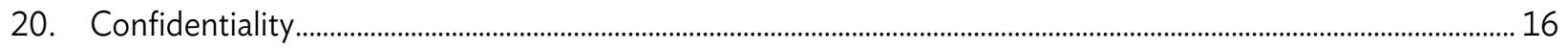

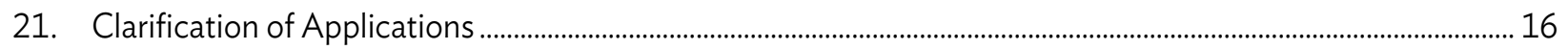

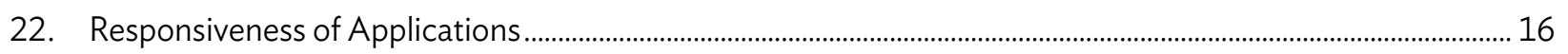

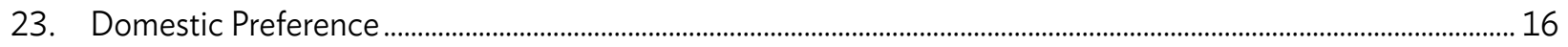

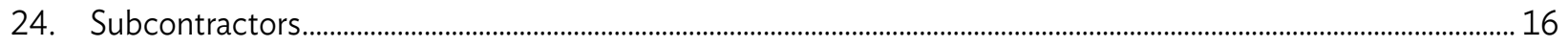

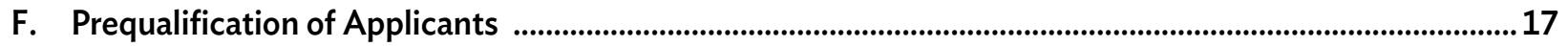

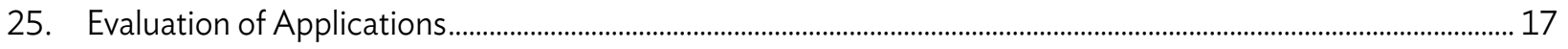

26. Employer's Right to Accept or Reject Applications ............................................................................................ 17

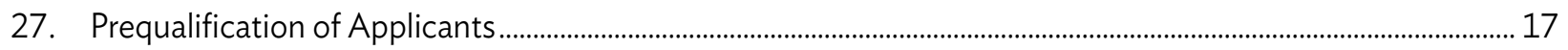

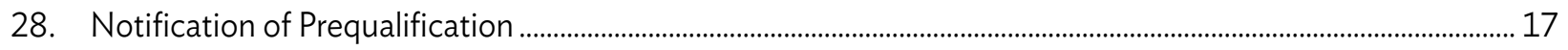

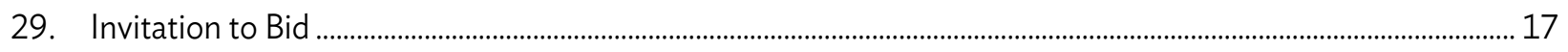

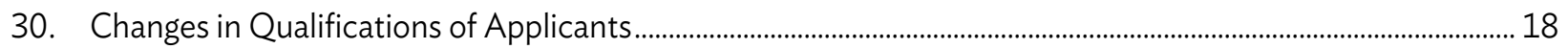

31. Bidding-Related Complaints ...................................................................................................................................................... 18 
A. General

1. Scope of Application

2. Source of Funds

3. Fraud and Corruption
1.1 In connection with the Invitation for Prequalification (IFP) indicated in Section 2 (Application Data Sheet) (ADS), the Employer, as defined in the ADS, issues this Prequalification Document to Applicants interested in bidding for the works described in Section 6 (Scope of Contract). The number of contracts and the name and identification of each contract as well as the open competitive bidding $(O C B)$ number corresponding to this prequalification are provided in the ADS.

2.1 The Borrower or Recipient (hereinafter called "Borrower") indicated in the ADS has applied for or received financing (hereinafter called "funds") from the Asian Development Bank (hereinafter called "ADB") toward the cost of the project named in the ADS. The Borrower intends to apply a portion of the funds to eligible payments under the contract(s) resulting from the bidding for which this prequalification is conducted (hereinafter called "Contract").

2.2 Payments by ADB will be made only at the request of the Borrower and upon approval by $A D B$ in accordance with the terms and conditions of the Financing Agreement between the Borrower and ADB (hereinafter called "Financing Agreement"), and will be subject in all respects to the terms and conditions of that Financing Agreement. No party other than the Borrower shall derive any rights from the Financing Agreement or have any claim to the funds.

3.1 ADB requires Borrowers (including beneficiaries of ADB-financed activity) and their personnel, as well as firms and individuals participating in an ADB-financed activity, including but not limited to, Bidders, Suppliers, and Contractors, ${ }^{1}$ agents, subcontractors, subconsultants, service providers, subsuppliers, manufacturers (including their respective officers, directors, employees and personnel) under ADBfinanced contracts to observe the highest standard of ethics during the procurement and execution of such contracts in accordance with ADB's Anticorruption Policy (1998, as amended from time to time). In pursuance of this policy, ADB

(a) defines, for the purposes of this provision, the terms set forth below as follows:

(i) "corrupt practice" means the offering, giving, receiving, or soliciting, directly or indirectly, anything of value to influence improperly the actions of another party;

(ii) "fraudulent practice" means any act or omission, including a misrepresentation, that knowingly or recklessly misleads, or attempts to mislead, a party to obtain a financial or other benefit or to avoid an obligation;

(iii) "coercive practice" means impairing or harming, or threatening to impair or harm, directly or indirectly, any party or the property of the party to influence improperly the actions of a party;

1 For the purpose of prequalification, the clause applies to "Applicants". 
(iv) "collusive practice" means an arrangement between two or more parties designed to achieve an improper purpose, including influencing improperly the actions of another party;

(v) "abuse" means theft, waste, or improper use of assets related to ADB- related activity, either committed intentionally or through reckless disregard;

(vi) "conflict of interest" means any situation in which a party has interests that could improperly influence that party's performance of official duties or responsibilities, contractual obligations, or compliance with applicable laws and regulations; and

(vii) "integrity violation" is any act, as defined under ADB's Integrity Principles and Guidelines (2015, as amended from time to time), which violates ADB's Anticorruption Policy, including (i) to (vi) above and the following: obstructive practice, violations of $A D B$ sanctions, retaliation against whistleblowers or witnesses, and other violations of ADB's Anticorruption Policy, including failure to adhere to the highest ethical standard.

(b) will reject a proposal for award if it determines that the Bidder recommended for award or any of its officers, directors, employees, personnel, subconsultants, subcontractors, service providers, suppliers or manufacturers has, directly or through an agent, engaged in corrupt, fraudulent, collusive, coercive, or obstructive practices or other integrity violations in competing for the Contract; $^{2}$

(c) will cancel the portion of the financing allocated to a contract if it determines at any time that representatives of the Borrower or of a beneficiary of ADB financing engaged in corrupt, fraudulent, collusive, coercive, or obstructive practices or other integrity violations during the procurement or the execution of that contract, without the Borrower having taken timely and appropriate action satisfactory to ADB to remedy the situation, including by failing to inform $A D B$ in a timely manner at the time they knew of the integrity violations;

(d) will impose remedial actions on a firm or an individual, at any time, in accordance with ADB's Anticorruption Policy and Integrity Principles and Guidelines, including declaring ineligible, either indefinitely or for a stated period of time, to participate ${ }^{3}$ in ADB-financed, -administered, or -supported activities or to benefit from an ADB-financed,-administered, or -supported contract, financially or otherwise, if it at any time determines that the firm or individual has, directly or through an agent, engaged in corrupt, fraudulent, collusive, coercive, or obstructive practices or other integrity violations; and

2 For the purpose of prequalification, item (b) is modified as "will reject a proposal for prequalification if it determines that the Applicant recommended for prequalification has, directly or through an agent, engaged in corrupt, fraudulent, collusive, coercive, or obstructive practices or other integrity violations in competing for the Contract."

3 Whether as a Contractor, Subcontractor, Consultant, Manufacturer or Supplier, or Service Provider; or in any other capacity (different names are used depending on the particular Bidding Document). 
(e) will have the right to require that a provision be included in bidding documents and in contracts financed, administered, or supported by ADB, requiring Bidders, suppliers, and contractors, consultants, manufacturers, service providers and other third parties engaged or involved in ADB-related activities, and their respective officers, directors, employees and personnel, to permit $A D B$ or its representative to inspect the site and their assets, accounts and records and other documents relating to the bid submission and contract performance and to have them audited by auditors appointed by ADB.

3.2 All Applicants, consultants, contractors, suppliers, manufacturers, service providers, and other third parties engaged or involved in ADB-related activities, and their respective officers, directors, employees and personnel, are obliged to cooperate fully in any investigation when requested by $A D B$ to do so. As determined on a case by case basis by $A D B$, such cooperation includes, but is not limited to, the following:

(a) being available to be interviewed and replying fully and truthfully to all questions asked;

(b) providing $\mathrm{ADB}$ with any items requested that are within the party's control including, but not limited to, documents and other physical objects;

(c) upon written request by $A D B$, authorizing other related entities to release directly to $A D B$ such information that is specifically and materially related, directly or indirectly, to the said entities or issues which are the subject of the investigation;

(d) cooperating with all reasonable requests to search or physically inspect their person and/or work areas, including files, electronic databases, and personal property used on ADB activities, or that utilizes ADB's information and communication technology (ICT) resources or systems (including mobile phones, personal electronic devices, and electronic storage devices such as external disk drives);

(e) cooperating in any testing requested by $A D B$, including but not limited to, fingerprint identification, handwriting analysis, and physical examination and analysis; and

(f) preserving and protecting confidentiality of all information discussed with, and as required by, $\mathrm{ADB}$.

3.3 All Applicants, consultants, contractors and suppliers shall require their officers, directors, employees, personnel, agents to ensure that, in its contracts with its subconsultants, Subcontractors and other third parties engaged or involved in ADBrelated activities, such subconsultants, Subcontractors and other third parties similarly are obliged to cooperate fully in any investigation when requested by $A D B$ to do so.

3.4 The Employer hereby puts the Applicant on notice that the Applicant or any Joint Venture partner of the Applicant (if any) may not be able to receive any payments under the Contract if the Applicant or any of its Joint Venture partners, as appropriate, is, or is owned (in whole or in part) by a person or entity subject to applicable sanctions. 


\section{Eligible Applicants}

4.1 An Applicant may be a natural person, private entity, or government-owned enterprise subject to ITA 4.6 or any combination of them with a formal intent to enterintoan agreement or under an existingagreement in the form of a Joint Venture. In the case of a Joint Venture,

(a) all partners shall be jointly and severally liable; and

(b) a Joint Venture shall nominate a Representative who shall have the authority to conduct all business for and on behalf of any and all the partners of the Joint Venture during the prequalification process; in the event the Joint Venture is prequalified, during the bidding process; and, in the event the Joint Venture is awarded the Contract, during contract execution.

4.2 An Applicant, and all partners constituting the Applicant, shall have the nationality of an eligible country, in accordance with Section 5 (Eligible Countries). An Applicant shall be deemed to have the nationality of a country if the Applicant is a citizen of that country; or is constituted, incorporated, or registered and operates in conformity with the provisions of the laws of that country. This requirement shall also apply to the determination of the nationality of proposed Subcontractors or Suppliers for any part of the Contract including related services.

4.3 At the time of bidding, Bidders shall not have a conflict of interest. All Bidders found to have a conflict of interest shall be disqualified. Bidders may be considered to be in a conflict of interest with one or more parties in the bidding process if any of, including but not limited to, the following apply:

(a) they have controlling shareholders in common; or

(b) they receive or have received any direct or indirect subsidy from any of them; or

(c) they have the same legal representative for purposes of this bid; or

(d) they have a relationship with each other, directly or through common third parties, that puts them in a position to have access to material information about or improperly influence the bid of another Bidder, or influence the decisions of the Employer regarding this bidding process; or

(e) a Bidder participates in more than one bid in this bidding process, either individually or as a partner in a Joint Venture, except for alternative offers if permitted by the Bidding Document. This will result in the disqualification of all Bids in which it is involved. However, subject to any finding of a conflict of interest in terms of ITA 4.3(a) to (d) above, this does not limit the participation of a Bidder as a Subcontractor in another bid or of a firm as a Subcontractor in more than one bid; or

(f) a Bidder, Joint Venture partner, associates, parent company, or any affiliated entity, participated as a Consultant in the preparation of the design or technical specifications of the works, plant and services that are the subject of the bid; or 
(g) a Bidder was affiliated with a firm or entity that has been hired (or is proposed to be hired) by the Employer or Borrower as Engineer for the Contract; or

(h) a Bidder would be providing goods, works, or nonconsulting services resulting from or directly related to consulting services for the preparation or implementation of the project specified in the ADS ITA 2.1 that it provided or were provided by any affiliate that directly or indirectly controls, is controlled by, or is under common control with that firm; or

(i) A Bidder that has a financial or familial relationship with staff of the Employer including project implementing/executing agency, or of a recipient of a part of the loan who: (i) are directly or indirectly involved in the preparation of the bidding documents or specifications of the contract, and/or the bid evaluation process of such contract; or (ii) would be involved in the implementation or supervision of such contract unless the conflict stemming from such relationship has been resolved in a manner acceptable to $A D B$ throughout the procurement process and execution of the contract.

4.4 Applicants found to be in conflict of interest situations at the time of prequalification but otherwise meeting requirements shall be invited to submit bids, however in the invitation for bids such applicants will be informed about conflict of interest and will be required to manage it in a manner acceptable to $A D B$ to comply with ITA 4.3 above.

4.5 A firm will not be eligible to participate in any procurement activities under an ADBfinanced, -administered, or -supported project while under temporary suspension or debarment by ADB pursuant to its Anticorruption Policy (see ITA 3), whether such debarment was directly imposed by $A D B$, or enforced by $A D B$ pursuant to the Agreement for Mutual Enforcement of Debarment Decisions. A bid from a temporarily suspended or debarred firm will be rejected and such bid may be in breach of debarment conditions, thereby subject to further ADB's investigation.

4.6 Government-owned enterprises in the Employer's country shall be eligible only if they can establish that they (i) are legally and financially autonomous, (ii) operate under commercial law, and (iii) are not in any way dependent agencies of the Employer.

4.7 Applicants shall be excluded if, by an act of compliance with a decision of the United Nations Security Council taken under Chapter VII of the Charter of the United Nations, the Borrower's country prohibits any import of goods from, or payments to, a particular country, person, or entity in respect of goods or services originating in that country. Where the Borrower's country prohibits payments to a particular person or entity or for particular goods or services by such an act of compliance, that firm shall be excluded.

4.8 Applicants shall provide such evidence of their continued eligibility satisfactory to the Employer, as the Employer shall reasonably request.

5. Eligible Materials, Equipment, and Services
5.1 The materials, equipment, and services to be supplied under the Contract and financed by ADB shall have as their country of origin in an eligible country of ADB; see Section 5 (Eligible Countries). 


\section{B. Contents of Prequalification Document}

6. Sections of the Prequalification Document
7. Clarification of Prequalification Document
6.1 The Prequalification Document consists of Parts I and II which include all the sections indicated below, and should be read in conjunction with any addenda issued in accordance with ITA 8.

\section{PART I Prequalification Procedures}

- Section 1 Instructions to Applicants (ITA)

- Section 2 Application Data Sheet (ADS)

- Section 3 Qualification Criteria (QLC)

- Section 4 Application Forms (APF)

- Section 5 Eligible Countries (ELC)

\section{PART II Requirements}

- Section 6 Scope of Contract (SOC)

6.2 The IFP issued by the Employer is not part of the Prequalification Document.

6.3 The Employer is not responsible for the completeness of the Prequalification Document and its addenda, if they were not obtained directly from the source stated by the Employer in the IFP.

6.4 The Applicant is expected to examine all instructions, forms, and terms in the Prequalification Document and to furnish all information or documentation required by the Prequalification Document. The information or documentation shall be complete, accurate, current, and verifiable. The Employer shall have the right to conduct independent checks to determine the completeness and accuracy of the information or documentation provided by the Applicant, and to take remedial actions, including rejection of the Applicant, as appropriate.

7.1 A prospective Applicant requiring any clarification on the Prequalification Document shall contact the Employer in writing at the Employer's address indicated in the ADS. The Employer will respond in writing to any request for clarification, provided that such request is received no later than 14 days prior to the deadline for submission of Applications. The Employer shall forward copies of its response to all Applicants who have acquired the Prequalification Document, including a description of the inquiry but without identifying its source, subject to ITA 6.3. Should the Employer deem it necessary to amend the Prequalification Document as a result of a request for clarification, it shall do so following the procedure under ITA 8 and in accordance with the provisions of ITA 17.2.

7.2 The Applicant's designated representative is invited to attend a pre-Application meeting, if indicated in the ADS. During this pre-Application meeting, prospective Applicants may request clarification of the project requirements, the criteria for qualifications or any other aspects of the Prequalification Document. Nonattendance at the pre-Application meeting will not be a cause for disqualification of an Applicant.

7.3 Minutes of the pre-Application meeting, if applicable, including the text of the questions asked by Applicants, including those during the meeting (without identifying the source) and the responses given, together with any responses prepared after the meeting will be transmitted promptly to all prospective 
Applicants who have obtained the Prequalification Document. Any modification to the Prequalification Document that may become necessary as a result of the pre-Application meeting shall be made by the Employer exclusively through the use of an Addendum pursuant to ITA 8.2 and not through the minutes of the pre-Application meeting.

8. Amendment of Prequalification Document
8.1 At any time prior to the deadline for submission of Applications, the Employer may amend the Prequalification Document by issuing addenda.

8.2 Any addendum issued shall be part of the Prequalification Document and shall be communicated in writing to all who have obtained the Prequalification Document from the Employer in accordance with ITA 6.3.

8.3 To give prospective Applicants reasonable time in which to take an addendum into account in preparing their Applications, the Employer may, at its discretion, extend the deadline for the submission of Applications, pursuant to ITA 17.2.

\section{Preparation of Applications}

\section{Cost of Applications}

10. Language of Application

\section{Documents Comprising the Application}

\section{Application Submission Sheet}

9.1 The Applicant shall bear all costs associated with the preparation and submission of its Application, and the Employer shall in no case be responsible or liable for those costs, regardless of the conduct or outcome of the prequalification process.

10.1 The Application, as well as all correspondence and documents relating to the prequalification exchanged by the Applicant and the Employer, shall be written in the English language. Supporting documents and printed literature that are part of the Application may be in another language, provided they are accompanied by an accurate translation of the relevant passages into the English language, in which case, for purposes of interpretation of the Application, the translation shall govern.

11.1 The Application shall comprise the following:

(a) Application Submission Sheet, in accordance with ITA 12;

(b) written confirmation authorizing the signatory of the Application to commit the Applicant, in accordance with ITA 15.3;

(c) documentary evidence establishing the Applicant's eligibility to prequalify, in accordance with ITA 13;

(d) documentary evidence establishing the Applicant's qualifications, in accordance with ITA 14; and

(e) any other document required as specified in the ADS.

12.1 The Applicant shall prepare an Application Submission Sheet using the form furnished in Section 4 (Application Forms). This form must be completed without any alteration to the text, and no substitutes shall be accepted. All blank spaces shall be filled in with the information requested. 
13. Documents Establishing the Eligibility of the Applicant

14. Documents Establishing the Qualifications of the Applicant

15. Format and Signing of the Application
13.1 To establish its eligibility in accordance with ITA 4, the Applicant shall complete the eligibility declarations in the Application Submission Sheet and Forms ELI 1 and 2, included in Section 4 (Application Forms).

14.1 To establish its qualifications to perform the Contract in accordance with Section 3 (Qualification Criteria), the Applicant shall provide the information requested in the corresponding Information Sheets included in Section 4 (Application Forms).

15.1 The Applicant shall prepare one original set of the documents comprising the Application as described in ITA 11 and clearly mark it "ORIGINAL." The original of the Application shall be typed or written in indelible ink and shall be signed by a person duly authorized to sign on behalf of the Applicant.

15.2 The Applicant shall submit copies of the signed original Application, in the number specified in the ADS, and clearly mark them "COPY." In the event of any discrepancy between the original and the copies, the original shall prevail.

15.3 The requirements regarding the legal instrument evidencing the authorization to represent and sign on behalf of the Applicant shall be as specified in the ADS. The name and position held by each person signing the authorization must be typed or printed below the signature. If an Applicant submits a deficient authorization, the Application shall not be rejected in the first instance. The Employer shall request the Applicant to submit an acceptable authorization within the number of days as specified in the ADS. Failure to provide an acceptable authorization within the period stated in the Employer's request shall cause the rejection of the Application.

15.4 Applications submitted by an existing or intended Joint Venture shall include an undertaking signed by all partners

(a) stating that all partners shall be jointly and severally liable; and

(b) nominating a Representative who shall have the authority to conduct all business for and on behalf of any and all the partners of the Joint Venture during the prequalification process; in the event the Joint Venture is prequalified, during the bidding process; and, in the event the Joint Venture is awarded the Contract, during contract execution.

\section{Submission of Applications}

16. Sealing and Marking of Applications
16.1 The Applicant shall enclose the original and the copies of the Application in a sealed envelope which shall

(a) bear the name and address of the Applicant;

(b) be addressed to the Employer, in accordance with ITA 17.1; and

(c) bear the specific identification of this prequalification process indicated in ADS 1.1. 
16.2 If the envelope is not sealed and marked as required, the Employer will assume no responsibility for the misplacement of the Application.

17. Deadline for Submission of Applications

18. Late Applications

19. Opening of Applications
17.1 Applications must be received by the Employer at the address and no later than the deadline indicated in the ADS.

17.2 The Employer may, at its discretion, extend the deadline for the submission of Applications by amending the Prequalification Document in accordance with ITA 8, in which case all rights and obligations of the Employer and the Applicants subject to the previous deadline shall thereafter be subject to the deadline as extended.

18.1 The Employer reserves the right to accept or reject late Applications.

19.1 The Employer shall open all Applications at the date, time and place specified in the ADS, subject to ITA18.1.

19.2 The Employer shall prepare a record of the opening of Applications that shall include, as a minimum, the name of the Applicant. A copy of the record shall be distributed to all Applicants.

\section{E. Evaluation of Applications}

20. Confidentiality

21. Clarification of Applications

22. Responsiveness of Applications

\section{Domestic} Preference

24. Subcontractors
20.1 Information relating to the evaluation of Applications, and recommendation for prequalification, shall not be disclosed to Applicants or any other persons not officially concerned with such process until the notification of prequalification is made to all Applicants.

20.2 From the deadline for submission of Applications to the time of notification of the results of the prequalification in accordance with ITA 28, if any Applicant wishes to contact the Employer on any matter related to the prequalification process, it may do so in writing.

21.1 To assist in the evaluation of Applications, the Employer may, at its discretion, ask any Applicant for a clarification of its Application which shall be submitted within a stated reasonable period of time. Any request for clarification and all clarifications shall be in writing.

21.2 If an Applicant does not provide clarifications of the information requested by the date and time set in the Employer's request for clarification, its Application may be rejected.

22.1 The Employer may reject any Application which is not responsive to the requirements of the Prequalification Document, subject to ITA 21.

23.1 If so indicated in the ADS, domestic preference shall apply in the bidding process resulting from this prequalification.

24.1 Applicants shall state in the Application Submission Sheet whether they intend to subcontract any of the key activities specified in Section 3 (Qualification Criteria).

24.2 The Applicant shall not propose to subcontract the entire scope of the contract. However, if an Applicant intends to subcontract any of the key activities listed in 
criterion 4.2 of Section 3 (Qualification Criteria), then such key activities and the proposed Subcontractors (Specialist Subcontractors) shall be clearly identified in Section 4 (Application Forms), Forms ELI - 2 and EXP - 2. Such Specialist Subcontractors shall meet the corresponding qualification requirements specified in Section 3 (Qualification Criteria). A formal intent to enter into an agreement with the Specialist Subcontractors in the form of a letter jointly signed by the Applicant and the Specialist Subcontractor should be submitted together with the Application. At the time of bidding, the Bidder shall use in its bid only Specialist Subcontractors prequalified during the prequalification exercise.

24.3 Unless otherwise stated in the ADS, the Employer does not intend for the contractor to executeany specific elements of the contract through nominated subcontractors.

\section{F. Prequalification of Applicants}

\section{Evaluation of} Applications

26. Employer's Right to Accept or Reject Applications

27. Prequalification of Applicants

28. Notification of Prequalification

29. Invitation to Bid
25.1 The Employer shall use only the criteria and methods defined in Section 3 (Qualification Criteria) to evaluate the qualifications of the Applicants, and proposed Subcontractors.

25.2 Only the qualifications of proposed Specialist Subcontractors with respect to "Experience in Key Activities" that have been identified in the Application pursuant to ITA 24.2 will be considered in the evaluation of an Applicant. However, the financial resources of Specialist Subcontractors may not be added to those of the Applicant for purposes of prequalification of the Applicant.

25.3 Unless otherwise indicated in the ADS, this prequalification shall be for a single contract.

25.4 Unless permitted in the ADS, the qualifications of other firms such as the Applicant's subsidiaries, parent entities, or affiliates shall not be considered.

26.1 The Employer reserves the right to accept or reject any Application, and to annul the prequalification process and reject all Applications at any time, without thereby incurring any liability to Applicants.

27.1 All Applicants, including their proposed Specialist Subcontractors, whose Applications have been determined to be substantially responsive to the requirements of the Prequalification Document and who have met or exceeded the specified criteria shall be prequalified by the Employer.

28.1 Once the Employer has completed the evaluation of the Applications it shall notify all Applicants in writing of the names of those Applicants who have been prequalified. In addition, those Applicants who have been disqualified will be informed separately.

29.1 Promptly after the notification of the results of the prequalification, the Employer shall invite bids from all the Applicants that have been prequalified.

29.2 Bidders may be required to provide bid security or a Bid-Securing Declaration acceptable to the Employer for an amount as specified in the bidding document. 
30. Changes in Qualifications of Applicants
30.1 Any change in the structure or formation of an Applicant after being prequalified in accordance with ITA 27 and invited to bid (including, in the case of a Joint Venture, any change in the structure or formation of any member and also including any change in any specialist subcontractor whose qualifications were considered to prequalify the Applicant) shall be subject to the written approval of the Employer prior to the deadline for submission of Bids. Any such change should be submitted to the Employer not later than 14 days after the date of the Invitation for Bids. Such approval shall be denied if

(a) a prequalified applicant proposes to associate with a disqualified applicant or in case of a disqualified Joint Venture, any of its members;

(b) as a consequence of the change, the Applicant no longer substantially meets the qualification criteria set forth in Section 3 (Qualification Criteria); or

(c) in the opinion of the Employer, the change may result in a substantial reduction in competition.

31. Bidding-Related 31.1 The procedures for dealing with Bidding-Related Complaints arising out of this Complaints

prequalification process are specified in the ADS. 


\section{Section 2: Application Data Sheet}

This Section 2 (Application Data Sheet) (ADS) contains information and provisions that are specific to a particular prequalification process. The Employer must specify in the ADS only the information that the Instructions to Applicant (ITA) request to be specified in the ADS. All information shall be provided; no clause shall beleftblank.

To facilitate the preparation of the ADS, its clauses are numbered with the same numbers as the corresponding ITA clauses. This guide provides information to the Employer on how to enter all required information.

\section{A. General}

\begin{tabular}{|l|l|}
\hline ITA 1.1 & The identification of the Invitation for Prequalification is: [insert identification number] \\
\hline ITA 1.1 & The name of the Employer is: [insert complete name of the Employer] \\
\hline ITA 1.1 & The names, identification, and number of the contracts are: [insert as required] \\
\hline ITA 1.1 & $\begin{array}{l}\text { The name and identification number of the open competitive bidding (OCB) are: [insert name and } \\
\text { identification number of the OCB] }\end{array}$ \\
\hline ITA 2.1 & The name of the Borrower is: [insert complete name] \\
\hline ITA 2.1 & The name of the Project is: [insert complete name] \\
\hline
\end{tabular}

\section{B. Contents of the Prequalification Document}

\begin{tabular}{|c|c|}
\hline ITA 7.1 & $\begin{array}{l}\text { For clarification purposes only, the Employer's address is: [insert all information required below] } \\
\text { Attention: [insert full name of the person, if applicable] } \\
\text { Street address: [insert street address and number] } \\
\text { Floor/Room number: [insert floor and room number, if applicable] } \\
\text { City: [insert name of the city or town] } \\
\text { ZIP code: [insert postal (ZIP) code, if applicable] } \\
\text { Country: [insert name of country] } \\
\text { Telephone: [insert telephone number including country and city codes] } \\
\text { Fax: [insert fax number with country and city codes] } \\
\text { E-mail: [insert e-mail address, if applicable] }\end{array}$ \\
\hline ITA 7.2 & $\begin{array}{l}\text { Pre-Application Meeting will be held: }[\text { Yes/No } \\
\text { [If yes, please add the address, date and time of the meeting] }\end{array}$ \\
\hline
\end{tabular}




\section{Preparation of Applications}

\begin{tabular}{|l|l|}
\hline ITA 11.1 (e) & $\begin{array}{l}\text { The Applicant shall submit with its Application the following additional documents: } \\
\text { [Specify any additional document not already listed in ITA 11.1 that must be submitted with the Application ] }\end{array}$ \\
\hline ITA 15.2 & $\begin{array}{l}\text { In addition to the original, the number of copies to be submitted with the Application is: [insert } \\
\text { number of copies required] }\end{array}$ \\
\hline ITA 15.3 & $\begin{array}{l}\text { The requirements regarding the legal instrument evidencing the authorization to represent and } \\
\text { sign on behalf of the Applicant shall be: [insert the name and description of the documentation required to } \\
\text { demonstrate the authority of the signatory to sign the Application. Employer may wish to consider the following } \\
\text { language: "An organizational document, board resolution or its equivalent, or power of attorney } \\
\text { specifying the representative's authority to sign the Application on behalf of, and to legally bind, } \\
\text { the Applicant. If the Applicant is an intended or an existing Joint Venture, the power of attorney } \\
\text { should be signed by all partners and specify the authority of the named representative of the Joint } \\
\text { Venture to sign on behalf of, and legally bind, the intended or existing Joint Venture. If the Joint } \\
\text { Venture has not yet been formed, also include evidence from all proposed Joint Venture partners } \\
\text { of their intent to enter into a Joint Venture in the event of a contract award."] }\end{array}$ \\
\hline ITA 15.3 & $\begin{array}{l}\text { The Applicant shall submit an acceptable authorization within [insert number of days, normally 14 } \\
\text { days] days. }\end{array}$
\end{tabular}

\section{Submission of Applications}

\begin{tabular}{|c|c|}
\hline ITA 17.1 & $\begin{array}{l}\text { For Application submission purposes only, the Employer's address is: [insert all information required } \\
\text { below] } \\
\text { Attention: } \\
\text { Street address: } \\
\text { Floor/Room number: } \\
\text { City: } \\
\text { ZIP code: } \\
\text { Tountry: } \\
\text { Fax: } \\
\text { Thephone: } \\
\text { Date: [insert day, month and year, i.e., } 15 \text { June 2018] } \\
\text { Time: [insert time and identify if a.m. or p.m., i.e., 2:00 p.m.] }\end{array}$ \\
\hline
\end{tabular}




\begin{tabular}{|c|c|}
\hline ITA 19.1 & $\begin{array}{l}\text { The application opening shall take place at: [insert all required and applicable information] } \\
\text { Street address: }\end{array}$ \\
\hline
\end{tabular}

\section{E. Evaluation of Applications}

\begin{tabular}{|c|c|}
\hline ITA 23.1 & $\begin{array}{l}\text { Domestic preference [insert "shall" or "shall not" ] apply in the bidding process corresponding to } \\
\text { this prequalification. } \\
\text { [If domestic preference applies, insert "The procedure for evaluation will be specified in the bidding } \\
\text { document."] }\end{array}$ \\
\hline ITA 24.3 & $\begin{array}{l}\text { The Employer [insert "intends" or "does not intend"] for the Contractor to execute any specific } \\
\text { elements of the contract through nominated subcontractors. } \\
\text { [If the Employer intends to execute specific parts of the contract by nominated subcontractors, insert, "The } \\
\text { specific parts of the contract and the respective Subcontractors are: }\end{array}$ \\
\hline
\end{tabular}

\section{F. Prequalification of Applicants}

\begin{tabular}{|l|l}
\hline ITA 25.3 & $\begin{array}{l}\text { [Use the text below in case of a single contract] } \\
\text { As stipulated in ITA 1.1, this prequalification exercise shall be for a single contract. } \\
\text { Or } \\
\text { [Use the text below in case of multiple contracts] } \\
\text { As stipulated in ITA 1.1, this prequalification exercise shall be for multiple contracts. [Continue } \\
\text { this sentence with one of the following two alternatives taking into account the advice provided in the User's Guide, } \\
\text { Page 2, Multiple Contracts] } \\
\text { [Alternative 1] } \\
\text { The Employer will prequalify each Applicant for a maximum contract value (bidding capacity). } \\
\text { An Applicant shall be allowed to bid for any contract within his bidding capacity, however, the } \\
\text { Applicant may only be awarded a maximum number of contracts for which the Applicant meets } \\
\text { the aggregated requirements of such contract combination (award capacity). A Bidder's award } \\
\text { capacity will be determined during bid evaluation when additional information such as (i) average } \\
\text { annual turnover, (ii) financial resources and current contract commitments, (iii) equipment to be } \\
\text { allocated, and (iv) personnel to be fielded will be assessed. } \\
{[\text { Alternative 2] }} \\
\text { The Employer will prequalify Applicants for each contract separately. Applicants shall indicate in } \\
\text { their Applications for which contract they wish to be prequalified. }\end{array}$
\end{tabular}




\begin{tabular}{|c|c|}
\hline ITA 25.4 & $\begin{array}{l}\text { [Choose one of the following options as appropriate.] } \\
\text { The qualifications of other firms such as the Applicant's subsidiaries, parent entities, or affiliates } \\
\text { shall not be permitted. } \\
\text { [or] } \\
\text { The qualifications of other firms such as the Applicant's subsidiaries, parent entities, or affiliates } \\
\text { shall be permitted for criteria } 3 \text { Financial Situation in Section 3. The other firms must satisfy the } \\
\text { criteria stated in } 1 \text { Eligibility in Section } 3 \text {. } \\
\text { [or] } \\
\text { The qualifications of other firms such as the Applicant's subsidiaries, parent entities, or affiliates } \\
\text { shall be permitted for criterion } 4.1 \text { Contracts of Similar Size and Nature and/or } 4.2 \text { Construction } \\
\text { Experience in Key Activities in Section 3. The other firms must satisfy the criteria stated in } \\
1 \text { Eligibility in Section } 3 \text {. } \\
\text { [or] } \\
\text { The qualifications of other firms such as the Applicant's subsidiaries, parent entities, or affiliates } \\
\text { shall be permitted for criteria } 3 \text { Financial Situation and } 4.1 \text { Contracts of Similar Size and Nature } \\
\text { and/or } 4.2 \text { Construction Experience in Key Activities in Section 3. The other firms must satisfy } \\
\text { the criteria stated in } 1 \text { Eligibility in Section } 3 \text {. } \\
\text { [If permitted, add "The Applicant shall provide the Affiliate Company Guarantee Form included in } \\
\text { Section } 4 \text { (Application Forms) filled out and signed by each subsidiary, parent entity, or affiliate } \\
\text { that the Applicant submits for consideration of the Employer in determining its qualifications."] }\end{array}$ \\
\hline ITA 31.1 & $\begin{array}{l}\text { The procedures for Bidding-Related Complaints are referenced in the Procurement Regulations } \\
\text { for ADB Borrowers (Appendix 7). The Applicant should submit its complaint following these } \\
\text { procedures, in writing, to: } \\
\text { For the attention: [insert full nameofperson receivingcomplaints] } \\
\text { Title/position: [insert title/position] } \\
\text { Employer: [insert name of Employer] } \\
\text { E-mail address: [insert e-mail address] } \\
\text { Fax number: [insert fax number] delete if not used] }\end{array}$ \\
\hline
\end{tabular}




\section{Section 3: Qualification Criteria}

This Section 3 (Qualification Criteria) (QLC) contains all the criteria and methods that the Employer will use to evaluate Applications. The information to be provided in relation to each criterion and the definitions of the corresponding terms are included in the respective Application Forms.

$A D B$ requires Bidders to be prequalified by meeting predefined, precise minimum requirements. The method entails setting pass-fail criteria which, if not met by the Applicant, result in disqualification.

The criteria adopted must relate to characteristics that are essential to ensure satisfactory execution of the contract, and must be stated in unambiguous terms. In essence, the criteria must be chosen so that only Contractors who are well qualified to carry out the contract are permitted to bid. The criteria must also be set so that they neither inhibit competition nor set a predetermined number of firms to be prequalified. All firms that meet the criteria should be invited to bid.

An Applicant's capabilities to perform the contracts satisfactorily are established in respect of the following:

1. Eligibility

2. Historical Contract Nonperformance

3. Financial Situation

4. Experience

\section{Table of Criteria}

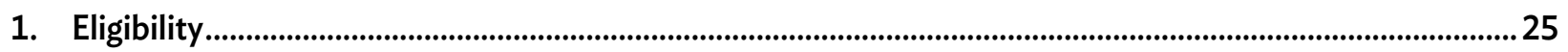

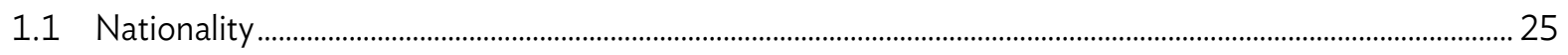

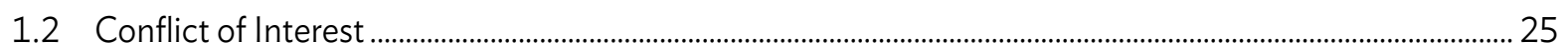

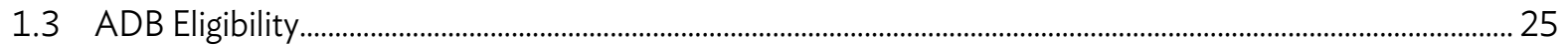

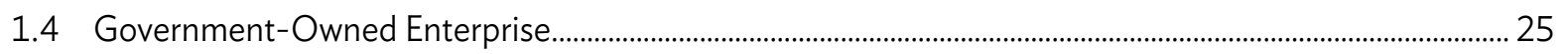

1.5 United Nations Eligibility ........................................................................................................................................ 25

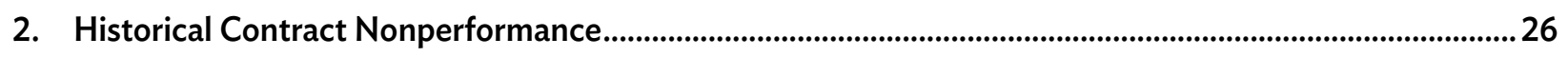

2.1 History of Nonperforming Contracts ............................................................................................................................ 26

2.2 Pending Litigation and Arbitration .................................................................................................................. 27

2.3 Declaration: Environmental, Health and Safety Past Performance ................................................................... 28 
3. Financial Situation.

3.1 Historical Financial Performance................................................................................................................................ 29

3.2 A: For Civil Works Contract - Average Annual Construction Turnover ........................................................ 30

B: For Plant - Design, Supply, and Installation Contract - Average Annual Turnover................................... 31

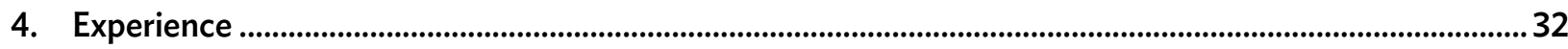

A: For Civil Works Contract........................................................................................................................................ 32

4.1 Contracts of Similar Size and Nature ................................................................................................................... 32

4.2 Construction Experience in Key Activities................................................................................................... 34

4.3 Specific Experience in Managing Environmental, Health and Safety Aspects ............................................. 36

B: For Plant - Design, Supply, and Installation Contract.......................................................................................... 37

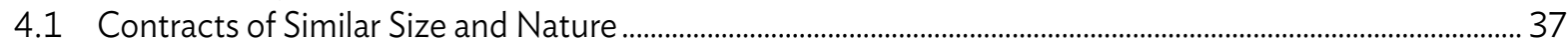

4.2 Experience in Key Activities........................................................................................................................... 39

4.3 Specific Experience in Managing Environmental, Health and Safety Aspects ............................................. 41

5. Organizational Environmental, Health and Safety System ....................................................................... 42

5.1 Environmental, Health and Safety Certification .................................................................................................... 42

5.2 Environmental, Health and Safety Documentation ........................................................................................... 43

5.3 Environmental, Health and Safety Dedicated Personnel ............................................................................ 44 


\section{NOTE}

The qualification criteria described below are pass or fail criteria. Applicants must meet all these qualification criteria. In a case where (i) all applicants fail to meet any of the criteria, or (ii) there is a limited number of qualified applicants (i.e., only one or two); or (iii) there is no adequate number of applications received (i.e., only one, two, or three), the Employer may, with prior ADB approval, cancel the prequalification process and invite bids on a postqualification basis with the appropriate modifications of the qualification requirements that were used for the prequalification exercise.

\section{Eligibility}

\begin{tabular}{|c|c|c|c|c|c|}
\hline Criteria & \multicolumn{4}{|c|}{ Compliance Requirements } & Documents \\
\hline & & \multicolumn{3}{|c|}{ Joint Venture } & \multirow[b]{2}{*}{$\begin{array}{l}\text { Submission } \\
\text { Requirements }\end{array}$} \\
\hline Requirement & Single Entity & $\begin{array}{c}\text { All Partners } \\
\text { Combined }\end{array}$ & $\begin{array}{c}\text { Each } \\
\text { Partner }\end{array}$ & $\begin{array}{c}\text { One } \\
\text { Partner }\end{array}$ & \\
\hline
\end{tabular}

\subsection{Nationality}

Nationality in accordance with ITA 4.2.

\begin{tabular}{c|c|c|c|}
$\begin{array}{c}\text { Must meet } \\
\text { requirement }\end{array}$ & $\begin{array}{c}\text { Must meet } \\
\text { requirement }\end{array}$ & $\begin{array}{c}\text { Must meet } \\
\text { requirement }\end{array}$ & $\begin{array}{c}\text { Not } \\
\text { applicable }\end{array}$
\end{tabular}

Forms

ELI - 1; ELI - 2

with attachments

\subsection{Conflict of Interest}

No conflicts of interest in accordance with ITA 4.3 and ITA 4.4.

\section{Must meet} requirement
Must meet

requirement
Must meet

requirement

Not
applicable
applicable
Application

Submission

Sheet

\subsection{ADB Eligibility}

Not having been declared ineligible by $A D B$, as described in ITA 4.5.

Must meet
requirement

Must meet

requirement

\begin{tabular}{|c|c|} 
Not & $\begin{array}{c}\text { Application } \\
\text { applicable }\end{array}$ \\
$\begin{array}{c}\text { Submission } \\
\text { Sheet }\end{array}$
\end{tabular}

\subsection{Government-Owned Enterprise}

\begin{tabular}{|l|c|c|c|c|c|}
\hline $\begin{array}{l}\text { Applicant required to meet } \\
\text { conditions of ITA 4.6. }\end{array}$ & $\begin{array}{c}\text { Must meet } \\
\text { requirement }\end{array}$ & $\begin{array}{c}\text { Must meet } \\
\text { requirement }\end{array}$ & $\begin{array}{c}\text { Must meet } \\
\text { requirement }\end{array}$ & $\begin{array}{c}\text { Not } \\
\text { applicable }\end{array}$ & $\begin{array}{c}\text { Forms } \\
\text { ELI }-1, \mathrm{ELI}-2 \\
\text { with attachments }\end{array}$ \\
\hline
\end{tabular}

\subsection{United Nations Eligibility}

\begin{tabular}{|l|c|c|c|c|c|}
\hline $\begin{array}{l}\text { Not having been excluded by an } \\
\text { act of compliance with a United } \\
\text { Nations Security Council } \\
\text { resolution in accordance with } \\
\text { ITA 4.7. }\end{array}$ & $\begin{array}{c}\text { Must meet } \\
\text { requirement }\end{array}$ & $\begin{array}{c}\text { Must meet } \\
\text { requirement }\end{array}$ & $\begin{array}{c}\text { Must meet } \\
\text { requirement }\end{array}$ & $\begin{array}{c}\text { Not } \\
\text { applicable }\end{array}$ & $\begin{array}{c}\text { Application } \\
\text { Submission } \\
\text { Sheet }\end{array}$ \\
\hline
\end{tabular}




\section{NOTE}

It is the obligation of the Employer to confirm an entity's eligibility by checking ADB's complete Sanctions List (for all applicants) at various stages of prequalification process including prequalification evaluation, prior to contract award, as well as during processing of contract variations, extensions or modifications. ADB has the right to monitor the Employer's compliance to this obligation.

ADB's Complete Sanctions List and the guide on how to get its access are available at https://www.adb.org/who-we-are/ integrity/sanctions.

\section{Historical Contract Nonperformance}

\subsection{History of Nonperforming Contracts}

\begin{tabular}{|c|c|c|c|c|c|}
\hline Criteria & \multicolumn{4}{|c|}{ Compliance Requirements } & Documents \\
\hline \multirow[b]{2}{*}{ Requirement } & \multirow[b]{2}{*}{ Single Entity } & \multicolumn{3}{|c|}{ Joint Venture } & \multirow[b]{2}{*}{$\begin{array}{l}\text { Submission } \\
\text { Requirements }\end{array}$} \\
\hline & & $\begin{array}{l}\text { All Partners } \\
\text { Combined }\end{array}$ & $\begin{array}{l}\text { Each } \\
\text { Partner }\end{array}$ & $\begin{array}{l}\text { One } \\
\text { Partner }\end{array}$ & \\
\hline $\begin{array}{l}\text { Nonperformance of a contract } \\
\text { did not occur as a result of } \\
\text { contractor default since 1st } \\
\text { January [insert year]. }\end{array}$ & $\begin{array}{l}\text { Must meet } \\
\text { requirement }\end{array}$ & $\begin{array}{l}\text { Must meet } \\
\text { requirement }\end{array}$ & $\begin{array}{l}\text { Must meet } \\
\text { requirement }\end{array}$ & $\begin{array}{c}\text { Not } \\
\text { applicable }\end{array}$ & Form CON-1 \\
\hline
\end{tabular}

a Nonperformance, as decided by the Employer, shall include all contracts where (a) nonperformance was not challenged by the contractor, including through referral to the dispute resolution mechanism under the respective contract; and (b) contracts that were so challenged but fully settled against the contractor. Nonperformance shall not include contracts where the Employer's decision was overruled by the dispute resolution mechanism. Nonperformance must be based on all information on fully settled disputes or litigation, i.e., dispute or litigation that has been resolved in accordance with the dispute resolution mechanism under the respective contract and where all appeal instances available to the Applicant have been exhausted.

b This requirement also applies to contracts executed by the Applicant as Joint Venture partner. 


\subsection{Pending Litigation and Arbitration}

Pending litigation and arbitration criterion [shall/shall not] apply. ${ }^{a}$

\begin{tabular}{|c|c|c|c|c|c|}
\hline Criteria & \multicolumn{4}{|c|}{ Compliance Requirements } & Documents \\
\hline \multirow[b]{2}{*}{ Requirement } & \multirow[b]{2}{*}{ Single Entity } & \multicolumn{3}{|c|}{ Joint Venture } & \multirow[b]{2}{*}{$\begin{array}{c}\text { Submission } \\
\text { Requirements }\end{array}$} \\
\hline & & $\begin{array}{c}\text { All Partners } \\
\text { Combined }\end{array}$ & $\begin{array}{c}\text { Each } \\
\text { Partner }\end{array}$ & $\begin{array}{c}\text { One } \\
\text { Partner }\end{array}$ & \\
\hline $\begin{array}{l}\text { All pending litigation, } \\
\text { arbitration or other material } \\
\text { events impacting the net worth } \\
\text { and/or liquidity of the bidder, if } \\
\text { any, shall be treated as resolved } \\
\text { against the Applicant and so } \\
\text { shall in total not represent more } \\
\text { than............... }{ }^{b} \text { percent } \\
\text { of the Applicant's net worth } \\
\text { calculated as the difference } \\
\text { between total assets and total } \\
\text { liabilities. }\end{array}$ & $\begin{array}{l}\text { Must meet } \\
\text { requirement }\end{array}$ & $\begin{array}{c}\text { Not } \\
\text { applicable }\end{array}$ & $\begin{array}{l}\text { Must meet } \\
\text { requirement }\end{array}$ & $\begin{array}{c}\text { Not } \\
\text { applicable }\end{array}$ & Form CON - 1 \\
\hline
\end{tabular}

a The Employer may choose whether to apply or not to apply this criterion:

1) If the Employer chooses to apply this criterion, it should indicate "shall apply" and use the table in 2.2.3, or

2) If the Employer chooses not to apply this criterion, it should indicate "shall not apply" and delete the table in 2.2.3.

${ }^{b}$ If the criterion is applied, the Employer should indicate a percentage within the range of $50 \%-100 \%$ of the Applicant's net worth. 


\subsection{Declaration: Environmental, Health and Safety Past Performance}

\begin{tabular}{|c|c|c|c|c|c|}
\hline Criteria & \multicolumn{4}{|c|}{ Compliance Requirements } & Documents \\
\hline \multirow[b]{2}{*}{ Requirement } & \multirow[b]{2}{*}{ Single Entity } & \multicolumn{3}{|c|}{ Joint Venture } & \multirow[b]{2}{*}{$\begin{array}{l}\text { Submission } \\
\text { Requirements }\end{array}$} \\
\hline & & $\begin{array}{c}\text { All Partners } \\
\text { Combined }\end{array}$ & $\begin{array}{c}\text { Each } \\
\text { Partner }\end{array}$ & $\begin{array}{c}\text { One } \\
\text { Partner }\end{array}$ & \\
\hline $\begin{array}{l}\text { Declare any civil works } \\
\text { contract that have been } \\
\text { suspended or terminated } \\
\text { and/or performance } \\
\text { security called by an } \\
\text { employer for reasons related } \\
\text { to the non-compliance of } \\
\text { any environmental, health } \\
\text { and safety contractual } \\
\text { obligations in the past five } \\
\text { years. }\end{array}$ & $\begin{array}{l}\text { Must make the } \\
\text { declaration. } \\
\text { If the bidder } \\
\text { proposes } \\
\text { Specialist Sub- } \\
\text { contractor/s } \\
\text { to meet EQC } \\
2.4 .2 \text {, those } \\
\text { Specialist Sub- } \\
\text { contractor/s } \\
\text { must also make } \\
\text { the declaration }\end{array}$ & $\begin{array}{c}\text { Not } \\
\text { applicable }\end{array}$ & $\begin{array}{l}\text { Each partner } \\
\text { must make the } \\
\text { declaration. } \\
\text { If the bidder } \\
\text { proposes } \\
\text { Specialist Sub- } \\
\text { contractor/s } \\
\text { to meet EQC } \\
2.4 .2 \text {, those } \\
\text { Specialist Sub- } \\
\text { contractor/s } \\
\text { must also make } \\
\text { the declaration. }\end{array}$ & $\begin{array}{c}\text { Not } \\
\text { applicable }\end{array}$ & Form CON-2 \\
\hline
\end{tabular}

a The Employer may use this information to seek further information or clarifications regarding corrective actions undertaken by the contractor during the bidding stage and the associated due diligence. 


\section{Financial Situation}

\subsection{Historical Financial Performance}

\begin{tabular}{|c|c|c|c|c|c|}
\hline Criteria & \multicolumn{4}{|c|}{ Compliance Requirements } & Documents \\
\hline \multirow[b]{2}{*}{ Requirement } & \multirow[b]{2}{*}{ Single Entity } & \multicolumn{3}{|c|}{ Joint Venture } & \multirow[b]{2}{*}{$\begin{array}{l}\text { Submission } \\
\text { Requirements }\end{array}$} \\
\hline & & $\begin{array}{l}\text { All Partners } \\
\text { Combined }\end{array}$ & $\begin{array}{c}\text { Each } \\
\text { Partner }\end{array}$ & $\begin{array}{c}\text { One } \\
\text { Partner }\end{array}$ & \\
\hline $\begin{array}{l}\text { Submission of audited financial } \\
\text { statements or, if not required } \\
\text { by the law of the Applicant's } \\
\text { country, other financial } \\
\text { statements acceptable to the } \\
\text { Employer, for the last ...... }{ }^{2} \\
\text { years to demonstrate the } \\
\text { current soundness of the } \\
\text { Applicant's financial position. } \\
\text { As a minimum, the Applicant's } \\
\text { net worth for the last year, } \\
\text { calculated as the difference } \\
\text { between total assets and total } \\
\text { liabilities should be positive. }\end{array}$ & $\begin{array}{l}\text { Must meet } \\
\text { requirement }\end{array}$ & $\begin{array}{c}\text { Not } \\
\text { applicable }\end{array}$ & $\begin{array}{l}\text { Must meet } \\
\text { requirement }\end{array}$ & $\begin{array}{c}\text { Not } \\
\text { applicable }\end{array}$ & $\begin{array}{c}\text { Form FIN - } 1 \\
\text { with attachments }\end{array}$ \\
\hline
\end{tabular}

a Insert time period between 3 and 5 years.

\section{NOTE}

The financial information provided by an Applicant should be reviewed in its entirety to allow a truly informed judgment, and the pass-fail decision on the financial position of the applicant should be given on this basis. Any abnormal feature that may lead to financial problems should alert the Employer to seek expert professional advice for further review and interpretation. 
A. For Civil Works Contract

3.2 Average Annual Construction Turnover

\begin{tabular}{|c|c|c|c|c|c|}
\hline Criteria & \multicolumn{4}{|c|}{ Compliance Requirements } & Documents \\
\hline \multirow[b]{2}{*}{ Requirement } & \multirow[b]{2}{*}{ Single Entity } & \multicolumn{3}{|c|}{ Joint Venture } & \multirow[b]{2}{*}{$\begin{array}{l}\text { Submission } \\
\text { Requirements }\end{array}$} \\
\hline & & $\begin{array}{c}\text { All Partners } \\
\text { Combined }\end{array}$ & $\begin{array}{c}\text { Each } \\
\text { Partner }\end{array}$ & $\begin{array}{c}\text { One } \\
\text { Partner }\end{array}$ & \\
\hline $\begin{array}{l}\text { Minimum average annual } \\
\text { construction turnover of } \\
\$ \ldots . . . . . . \text { a calculated as total } \\
\text { certified payments received } \\
\text { for contracts in progress or } \\
\text { completed, within the last } \\
\ldots . . . . . . \\
\text { b years. }\end{array}$ & $\begin{array}{l}\text { Must meet } \\
\text { requirement }\end{array}$ & $\begin{array}{l}\text { Must meet } \\
\text { requirement }\end{array}$ & $\begin{array}{c}\text { Must meet } \\
\ldots \ldots . . . \\
\text { of the } \\
\text { requirement }\end{array}$ & $\begin{array}{c}\text { Must meet } \\
\ldots \ldots . . . \\
\text { of the } \\
\text { requirement }\end{array}$ & Form FIN - 2 \\
\hline
\end{tabular}

a The amount stated should normally not be less than two times the annualized value of the subject contract, expressed as $2 \times \mathrm{V} / \mathrm{T}$; where $\mathrm{V}$ is the Employer's estimated cost (including contingencies), $\mathrm{T}$ is the contract duration in years. For contract duration of up to 1 year, T of " 1 " should be used. The multiplier of 2 may be reduced for very large contracts but should not be less than 1.5 .

b Insert number of years in words and figures and indicate time period between 3 and 5 years.

c The Employer is to define this value based on the minimum amount required that all partners of the Joint Venture must meet taking joint and several liability into account, usually at least $25 \%$.

$d$ The Employer is to define this value based on the minimum amount required that one partner of the Joint Venture must meet, usually at least $40 \%$. 


\section{B. For Plant - Design, Supply, and Installation Contract}

\subsection{Average Annual Turnover}

\begin{tabular}{|c|c|c|c|c|c|}
\hline Criteria & \multicolumn{4}{|c|}{ Compliance Requirements } & Documents \\
\hline \multirow[b]{2}{*}{ Requirement } & \multirow[b]{2}{*}{ Single Entity } & \multicolumn{3}{|c|}{ Joint Venture } & \multirow[b]{2}{*}{$\begin{array}{l}\text { Submission } \\
\text { Requirements }\end{array}$} \\
\hline & & $\begin{array}{c}\text { All Partners } \\
\text { Combined }\end{array}$ & $\begin{array}{c}\text { Each } \\
\text { Partner }\end{array}$ & $\begin{array}{c}\text { One } \\
\text { Partner }\end{array}$ & \\
\hline $\begin{array}{l}\text { Minimum average } \\
\text { annual turnover of } \$ \\
\ldots . . . .{ }^{a} \text { calculated as } \\
\text { total certified payments } \\
\text { received for contracts in } \\
\text { progress or completed, } \\
\text { within the last ............ } \\
\text { years. }\end{array}$ & $\begin{array}{l}\text { Must meet } \\
\text { requirement }\end{array}$ & $\begin{array}{l}\text { Must meet } \\
\text { requirement }\end{array}$ & $\begin{array}{c}\text { Must meet } \\
\ldots \ldots \ldots \\
\text { of the } \\
\text { requirement }\end{array}$ & $\begin{array}{c}\text { Must meet } \\
\ldots \ldots . . . \\
\text { of the } \\
\text { requirement }\end{array}$ & Form FIN - 2 \\
\hline
\end{tabular}

a The amount stated should normally not be less than two times the annualized value of the subject contract, expressed as $2 \times \mathrm{V} / \mathrm{T}$; where $\mathrm{V}$ is the Employer's estimated cost (including contingencies), $\mathrm{T}$ is the contract duration in years. For contract duration of up to 1 year, T of " 1 " should be used. The multiplier of 2 may be reduced for very large contracts but should not be less than 1.5.

b Insert number of years in words and figures and indicate time period between 3 and 5 years.

c The Employer is to define this value based on the minimum amount required that all partners of the Joint Venture must meet taking joint and several liability into account, usually at least $25 \%$.

$d$ The Employer is to define this value based on the minimum amount required that one partner of the Joint Venture must meet, usually at least $40 \%$. 


\section{Experience}

A. For Civil Works Contract

\subsection{Contracts of Similar Size and Nature}

\begin{tabular}{|c|c|c|c|c|c|}
\hline Criteria & \multicolumn{4}{|c|}{ Compliance Requirements } & Documents \\
\hline \multirow[b]{2}{*}{ Requirement } & \multirow[b]{2}{*}{$\begin{array}{l}\text { Single } \\
\text { Entity }\end{array}$} & \multicolumn{3}{|c|}{ Joint Venture } & \multirow[b]{2}{*}{$\begin{array}{l}\text { Submission } \\
\text { Requirements }\end{array}$} \\
\hline & & $\begin{array}{l}\text { All Partners } \\
\text { Combined }\end{array}$ & $\begin{array}{c}\text { Each } \\
\text { Partner }\end{array}$ & $\begin{array}{c}\text { One } \\
\text { Partner }\end{array}$ & \\
\hline $\begin{array}{l}\text { Participation as a contractor, Joint } \\
\text { Venture partner, or Subcontractor, } \\
\text { in at least one contract that has } \\
\text { been satisfactorily and substantially } \\
\text { a completed within the last ........ } \\
\text { years, and that is similar to the } \\
\text { proposed works, where the value of } \\
\text { the Applicant's participation exceeds } \\
\$ \ldots \ldots \ldots . . \text {. The similarity of the } \\
\text { Applicant's participation shall be } \\
\text { based on: d,e,f } \\
1 \ldots \\
2 \ldots \\
3 . . . .\end{array}$ & $\begin{array}{l}\text { Must meet } \\
\text { requirement }\end{array}$ & Not applicable & $\begin{array}{c}\text { Not } \\
\text { applicableg }\end{array}$ & $\begin{array}{l}\text { Must meet } \\
\text { requirement }\end{array}$ & Form EXP $-1^{\mathrm{h}}$ \\
\hline
\end{tabular}

Or

\begin{tabular}{|c|c|c|c|c|c|}
\hline $\begin{array}{l}\text { Participation as a contractor, Joint } \\
\text { Venture partner, or Subcontractor, } \\
\text { in at least two contracts that have } \\
\text { been satisfactorily and substantially }{ }^{a} \\
\text { completed within the last ...... }{ }^{\text {years }} \\
\text { and that are similar to the proposed } \\
\text { works, where the value of the } \\
\text { Applicant's participation under each } \\
\text { contract exceeds } \$ \ldots . . . .{ }^{\circ} \\
\text { The similarity of the Applicant's } \\
\text { participation shall be based on: }{ }^{\text {d, e, f }} \\
1 \ldots \\
2 \ldots \\
3 \ldots\end{array}$ & $\begin{array}{c}\text { Must meet } \\
\text { requirement }\end{array}$ & $\begin{array}{l}\text { Must meet } \\
\text { requirement as } \\
\text { follows: } \\
\text { (i) Either one partner } \\
\text { must meet } \\
\text { requirement; or } \\
\text { (ii) Any two partners } \\
\text { must each } \\
\text { demonstrate one } \\
\text { (1) satisfactorily } \\
\text { and substantially } \\
\text { completed } \\
\text { contract of similar } \\
\text { size, and nature }\end{array}$ & $\begin{array}{c}\text { Not } \\
\text { applicableg }^{g}\end{array}$ & $\begin{array}{c}\text { Not } \\
\text { applicable }\end{array}$ & Form EXP $-1^{\mathrm{h}}$ \\
\hline
\end{tabular}

a The requirement of "substantially completed contract" may vary from bid package to bid package. The requirement of "substantially completed contract" should be carefully reflected in the documents required to be submitted by applicants, to avoid potential issues in prequalification evaluation (refer Note 'h' below). For further guidance on substantial completion of contracts, refer to ADB's Guidance Note on Procurement: Open Competitive Bidding.

2 The Employer has the option of requiring either one or two contracts of similar size and nature and should choose the appropriate language for the table in 4.1. 
b Insert number of years in words and figures. The range is normally 5-10 years.

c Usually $80 \%$ of the estimated value of the subject contract. In case of repetitive and contiguous works (e.g., transmission lines, water pipeline), the Employer has the option of specifying a value that is between $50 \%$ and $80 \%$ of the subject contract value. If the contract value is not in the specific currency, the exchange rate to be used to calculate the value of the contract shall be the selling rate of the Borrower's central bank on the date of the contract.

d Specify major requirements in terms of any of the following: physical size, nature of works, complexity, methods, technology, or other characteristics.

e For contracts under which the Applicant participated as a Joint Venture partner or Subcontractor, only the Applicant's share, by value, shall be considered to meet this requirement.

f For contracts implemented by a Joint Venture contractor, if the Applicant comprises the same Joint Venture, the 'Single Entity' requirements will apply.

8 In case of complex works, the Employer may require each partner to demonstrate one satisfactorily and substantially completed contract of similar nature where such partner's value of participation exceeds $25 \%$ of the subject contract value.

${ }^{h}$ In addition to the submission requirement Form EXP - 1, the Applicant shall provide the following supporting documents:

[If the Employer will consider a "substantially completed contract" as one in which the works have been completed, insert the following text:

1. Signed Contract Agreement, and

2. Taking-Over Certificate, Contract Completion Certificate or Performance Certificate,

in sufficient detail to verify the contract name, value and completion time (or substantial completion). If the documents are other than in English, an accurate certified translation of these documents in English shall be provided.]

[If the Employer will consider a "substantially completed contract" as one in which the Contractor has completed all its obligations under the contract, insert the following text:

1. Signed Contract Agreement, and

2. Contract Completion Certificate or Performance Certificate,

in sufficient detail to verify the contract name, value and completion time. If the documents are other than in English, an accurate certified translation of these documents in English shall be provided.] 


\subsection{Construction Experience in Key Activities ${ }^{3}$}

4.2 (a) Mustbecomplied with bytheApplicant. In case of a Joint Venture Applicant, the Applicant or at least one of the partners must meet the requirement in the key activity. For contracts under which the Applicant participated as a Joint Venture partner, only the Applicant's designated scope of works under the contracts shall be considered to meet this requirement.

Table A

\begin{tabular}{|l|l|l|l|}
\multicolumn{1}{|c|}{ Criteria } & \multicolumn{2}{c|}{ Compliance Requirements } & Documents \\
\hline \multicolumn{1}{|c|}{ Requirement } & Single Entity & Joint Venture & $\begin{array}{c}\text { Submission } \\
\text { Requirements }\end{array}$ \\
\hline $\begin{array}{l}\text { For the above or other contracts } \\
\text { executed during the period } \\
\text { stipulated in 4.1, a minimum } \\
\text { construction experience in the } \\
\text { following key activities: }\end{array}$ & Must meet requirement & Must meet requirement & Form EXP $-2^{\mathrm{b}}$ \\
\hline $1 \ldots \ldots .$. & & & \\
\hline $2 \ldots \ldots . .$. & & & \\
\hline $3 .$. etc .... & & & \\
\hline
\end{tabular}

a Under Criterion 4.1, the specified requirements define the similarity of contracts, whereas the key activities or production rates to be specified under Criterion 4.2 define the required capability of the Applicant to execute key components of the Works. There shall not be any inconsistency or duplication of requirements between Criteria 4.1 and 4.2. For the rate of production, specify that the rate of production shall be on the basis of either the average during the entire specified period.

b Submission requirements: Form EXP - 2 shall be supported by documents such as Signed Contract Agreement, TakingOver Certificate or Contract Completion Certificate indicating the contract name, value. completion date (or percentage of substantial completion), activities performed by Joint Venture partners, and other relevant details sufficient to demonstrate compliance with the requirements.

3 The key activities criterion should test the applicant's experience of performing highly specialized construction activities (e.g., tunneling, dredging, and bridge construction) and achievement of specified production rates. 
4.2. (b) The Employer accepts any of the following activities to be subcontracted. They may be complied with by the Applicant or by its proposed Specialist Subcontractor.

If the key activity is to be undertaken by a Specialist Subcontractor, the Employer shall require evidence of the subcontracting agreement from the Applicant.

\section{Table B}

\begin{tabular}{|c|c|c|c|}
\hline Criteria & \multicolumn{2}{|c|}{ Compliance Requirements } & Documents \\
\hline Requirement & $\begin{array}{c}\text { Single Entity or Its Specialist } \\
\text { Subcontractors }\end{array}$ & $\begin{array}{l}\text { Joint Venture } \\
\text { or Its Specialist } \\
\text { Subcontractors }\end{array}$ & $\begin{array}{l}\text { Submission } \\
\text { Requirements }\end{array}$ \\
\hline $\begin{array}{l}\text { For the above or other contracts } \\
\text { executed during the period } \\
\text { stipulated in } 4.1 \text {, a minimum } \\
\text { construction experience is required } \\
\text { in the following key activities: } a, b\end{array}$ & Must meet requirement & Must meet requirement & Form EXP $-2^{c}$ \\
\hline $4 \ldots \ldots \ldots$ & & & \\
\hline $5 \ldots \ldots \ldots$ & & & \\
\hline 6 .. etc .... & & & \\
\hline
\end{tabular}

a Under Criterion 4.1, the specified requirements define the similarity of contracts, whereas the key activities or production rates to be specified under Criterion 4.2 define the required capability of the Applicant to execute key components of the Works. There shall be no inconsistency or duplication of requirements between Criteria 4.1 and 4.2. For the rate of production, specify that the rate of production shall be on the basis of the average during the entire specified period.

b The compliance requirement for each key activity that may be met by a specialist subcontractor must define whether the requirement can only be met by a single specialist subcontractor or whether two or more specialist subcontractors can jointly meet the requirement.

c Submission requirements: Form EXP - 2 shall be supported by documents such as Signed Contract Agreement, TakingOver Certificate or Contract Completion Certificate indicating the contract name, value. completion date (or percentage of substantial completion), activities performed by Joint Venture partners, and other relevant details sufficient to demonstrate compliance with the requirements. 
4.3 Specific Experience in Managing Environmental, Health and Safety Aspects

\begin{tabular}{|c|c|c|c|}
\hline Criteria & \multicolumn{2}{|c|}{ Compliance Requirements } & Documents \\
\hline Requirement & $\begin{array}{l}\text { Single Entity or } \\
\text { Its Specialist } \\
\text { Subcontractors }\end{array}$ & $\begin{array}{l}\text { Joint Venture } \\
\text { or Its Specialist } \\
\text { Subcontractors }\end{array}$ & $\begin{array}{c}\text { Submission } \\
\text { Requirements }\end{array}$ \\
\hline $\begin{array}{l}\text { For the contracts in } 4.1 \text { and } 4.2 \\
\text { above and/or any other contracts } \\
\text { [substantially completed and } \\
\text { under implementation] as prime } \\
\text { contractor, Joint Venture partner, or } \\
\text { Subcontractor between 1st January } \\
\ldots \ldots{ }^{a} \text { and Bid submission deadline, } \\
\text { experience in managing EHS } \\
\text { risks and impacts in the following } \\
\text { aspects: }\end{array}$ & Must meet requirement & $\begin{array}{l}\text { One member must meet } \\
\text { requirements } \\
\text { Or } \\
\text { All members must meet } \\
\text { requirements }\end{array}$ & Form EXP - 3 \\
\hline
\end{tabular}

a Insert year.

b Based on the EHS assessment, specify, as appropriate, specific experience requirements to manage EHS aspects. 


\section{B. For Plant - Design, Supply, and Installation Contract}

\subsection{Contracts of Similar Size and Nature ${ }^{4}$}

\begin{tabular}{|c|c|c|c|c|c|}
\hline Criteria & \multicolumn{4}{|c|}{ Compliance Requirements } & Documents \\
\hline \multirow[b]{2}{*}{ Requirement } & \multirow[b]{2}{*}{$\begin{array}{l}\text { Single } \\
\text { Entity }\end{array}$} & \multicolumn{3}{|c|}{ Joint Venture } & \multirow[b]{2}{*}{$\begin{array}{l}\text { Submission } \\
\text { Requirements }\end{array}$} \\
\hline & & $\begin{array}{c}\text { All Partners } \\
\text { Combined }\end{array}$ & $\begin{array}{c}\text { Each } \\
\text { Partner }\end{array}$ & $\begin{array}{c}\text { One } \\
\text { Partner }\end{array}$ & \\
\hline $\begin{array}{l}\text { Participation as a contractor, } \\
\text { Joint Venture partner, or } \\
\text { Subcontractor, in at least } \\
\text { one contract that has been } \\
\text { satisfactorily and substantially }{ }^{\text {a }} \\
\text { completed within the last ...... } \\
\text { years and that is similar to the } \\
\text { proposed contract, where } \\
\text { the value of the Applicant's } \\
\text { participation exceeds } \$ \ldots . . . . .{ }^{c} \text {. } \\
\text { The similarity of the Applicant's } \\
\text { participation shall be based on: }{ }^{\mathrm{d}, \mathrm{e}, \mathrm{f}} \\
1 \ldots \\
2 \ldots \\
3 \ldots\end{array}$ & $\begin{array}{l}\text { Must meet } \\
\text { requirement }\end{array}$ & Not applicable & $\begin{array}{c}\text { Not } \\
\text { applicableg }\end{array}$ & $\begin{array}{l}\text { Must meet } \\
\text { requirement }\end{array}$ & Form EXP $-1^{\mathrm{h}}$ \\
\hline
\end{tabular}

\begin{tabular}{|c|c|c|c|c|c|}
\hline 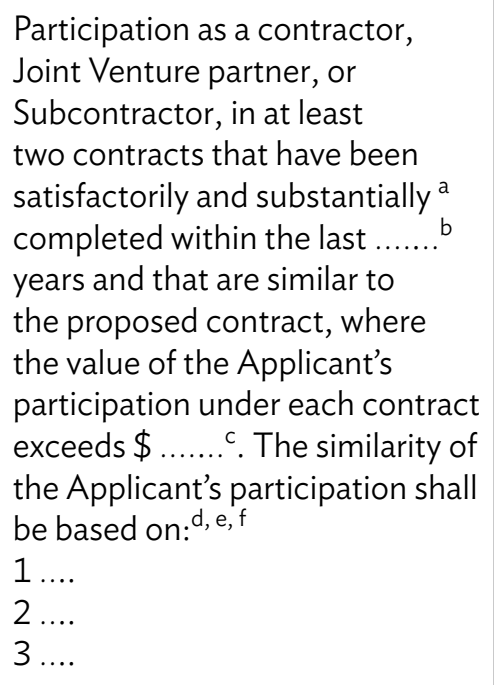 & $\begin{array}{c}\text { Must meet } \\
\text { requirement }\end{array}$ & $\begin{array}{l}\text { Must meet } \\
\text { requirement as } \\
\text { follows: } \\
\text { (i) Either one } \\
\text { partner } \\
\text { must meet } \\
\text { requirement; or } \\
\text { (ii) Any two partners } \\
\text { must each } \\
\text { demonstrate one } \\
\text { (1) satisfactorily } \\
\text { and substantially } \\
\text { completed } \\
\text { contract of } \\
\text { similar size, and } \\
\text { nature }\end{array}$ & $\begin{array}{c}\text { Not } \\
\text { applicable }\end{array}$ & $\begin{array}{c}\text { Not } \\
\text { applicable }\end{array}$ & Form EXP $-1^{\mathrm{h}}$ \\
\hline
\end{tabular}

a The requirement of "substantially completed contract" may vary from bid package to bid package. The requirement of "substantially completed contract" should be carefully reflected in the documents required to be submitted by applicants, to avoid potential issues in prequalification evaluation (refer Note ' $h$ ' below). For further guidance on substantial completion of contracts, refer to ADB's Guidance Note on Procurement: Open Competitive Bidding.

$4 \quad$ The Employer has the option of requiring either one or two contracts of similar size and nature and should choose the appropriate language for the table in 4.1. 
b Insert number of years in words and figures. The range is normally 5-10 years.

c Usually $80 \%$ of the estimated value of the subject contract. In case of repetitive and contiguous works (e.g., transmission lines, water pipeline) the Employer has the option of specifying a value that is between $50 \%$ and $80 \%$ of the subject contract value. If the contract value is not in the specific currency, the exchange rate to be used to calculate the value of the contract shall be the selling rate of the Borrower's central bank on the date of the contract.

d Specify major requirements in terms of any of the following: physical size, nature of works, complexity, methods, technology, or other characteristics.

e For contracts under which the Applicant participated as a Joint Venture partner or Subcontractor, only the Applicant's share, by value, shall be considered to meet this requirement.

${ }^{f}$ For contracts implemented by a Joint Venture contractor, if the Applicant comprises the same Joint Venture, the 'Single Entity' requirements will apply.

$g$ In case of complex works, the Employer may require each partner to demonstrate one satisfactorily and substantially completed contract of similar nature where such partner's value of participation exceeds $25 \%$ of the subject contract value.

$\mathrm{h}$ In addition to the submission requirement Form EXP - 1, the Applicant shall provide the following supporting documents:

[If the Employer will consider a "substantially completed contract" as one in which the works have been completed, insert the following text:

1. Signed Contract Agreement, and

2. Taking-Over Certificate, Contract Completion Certificate or Performance Certificate, in sufficient detail to verify the contract name, value and completion time (or substantial completion). If the documents are other than in English, an accurate certified translation of these documents in English shall be provided.]

[If the Employer will consider a "substantially completed contract" as one in which the Contractor has completed all its obligations under the contract, insert the following text:

1. Signed Contract Agreement, and

2. Contract Completion Certificate or Performance Certificate, in sufficient detail to verify the contract name, value and completion time. If the documents are other than in English, an accurate certified translation of these documents in English shall be provided.] 


\subsection{Experience in Key Activities ${ }^{5}$}

4.2(a) Must be complied with by the Applicant. In case of a Joint Venture Applicant, the Applicant at least one of the partners must meet the requirement in the keyactivity. For contracts under which the Applicant participated as a Joint Venture partner, only the Applicant's designated scope of works under the contracts shall be considered to meet this requirement.

Table A

\begin{tabular}{|l|l|l|l|}
\multicolumn{1}{|c|}{ Criteria } & \multicolumn{2}{c|}{ Compliance Requirements } & Documents \\
\hline \multicolumn{1}{|c|}{ Requirement } & Single Entity & Joint Venture & $\begin{array}{c}\text { Submission } \\
\text { Requirements }\end{array}$ \\
\hline $\begin{array}{l}\text { For the above or other contracts } \\
\text { executed during the period } \\
\text { stipulated in 4.1, a minimum } \\
\text { experience in the following key } \\
\text { activities: }\end{array}$ & Must meet requirement & Must meet requirement & Form EXP - 2a \\
\hline $1 \ldots \ldots . .$. & & & \\
\hline $2 \ldots \ldots . .$. & & & \\
\hline $3 \ldots$ etc .... & & & \\
\hline
\end{tabular}

a Submission requirements: Form EXP - 2 shall be supported by documents such as Signed Contract Agreement, TakingOver Certificate or Contract Completion Certificate indicating the contract name, value. completion date (or percentage of substantial completion), activities performed by Joint Venture partners, and other relevant details sufficient to demonstrate compliance with the requirements.

5 The key activities criterion should test the applicant's experience of performing highly specialized construction activities (e.g., tunneling, dredging, and bridge construction) and achievement of specified production rates. 
4.2 (b) The Employer accepts any of the following activities to be subcontracted. They may be complied with by the Applicant or by its proposed specialist subcontractor. If the key activity is to be undertaken by a Specialist Subcontractor, the Employer shall require evidence of the subcontracting agreement at the time of bidding.

Table B

\begin{tabular}{|c|c|c|c|}
\hline Criteria & \multicolumn{2}{|c|}{ Compliance Requirements } & Documents \\
\hline Requirement & $\begin{array}{l}\text { Single Entity or Its Specialist } \\
\text { Subcontractors }\end{array}$ & $\begin{array}{l}\text { Joint Venture } \\
\text { or Its Specialist } \\
\text { Subcontractors }\end{array}$ & $\begin{array}{c}\text { Submission } \\
\text { Requirements }\end{array}$ \\
\hline $\begin{array}{l}\text { For the above or other contracts } \\
\text { executed during the period } \\
\text { stipulated in } 4.1 \text {, a minimum } \\
\text { experience in the following key } \\
\text { activities: }{ }^{a, b}\end{array}$ & One must meet requirement & $\begin{array}{l}\text { One must meet } \\
\text { requirement }\end{array}$ & Form EXP $-2^{c}$ \\
\hline $4 \ldots \ldots \ldots$ & & & \\
\hline $5 \ldots \ldots \ldots$ & & & \\
\hline 6 .. etc .... & & & \\
\hline
\end{tabular}

a Under Criterion 4.1, the specified requirements define the similarity of contracts, whereas the key activities or production rates to be specified under Criterion 4.2 define the required capability of the Applicant to execute key components of the Works. There shall be no inconsistency or duplication of requirements between Criteria 4.1 and 4.2. For the rate of production, specify that the rate of production shall be on the basis of the average during the entire specified period.

b The compliance requirement for each key activity that may be met by a specialist subcontractor must define whether the requirement can only be met by a single specialist subcontractor or whether two or more specialist subcontractors can jointly meet the requirement.

c Submission requirements: Form EXP - 2 shall be supported by documents such as Signed Contract Agreement, TakingOver Certificate or Contract Completion Certificate indicating the contract name, value. completion date (or percentage of substantial completion), activities performed by Joint Venture partners, and other relevant details sufficient to demonstrate compliance with the requirements. 


\subsection{Specific Experience in Managing Environmental, Health and Safety Aspects}

\begin{tabular}{|c|c|c|c|}
\hline Criteria & \multicolumn{2}{|c|}{ Compliance Requirements } & Documents \\
\hline Requirement & $\begin{array}{l}\text { Single Entity or Its Specialist } \\
\text { Subcontractors }\end{array}$ & $\begin{array}{l}\text { Joint Venture } \\
\text { or Its Specialist } \\
\text { Subcontractors }\end{array}$ & $\begin{array}{l}\text { Submission } \\
\text { Requirements }\end{array}$ \\
\hline $\begin{array}{l}\text { For the contracts in } 4.1 \text { and } 4.2 \\
\text { above and/or any other contracts } \\
\text { [substantially completed and } \\
\text { under implementation] as prime } \\
\text { contractor, Joint Venture partner, } \\
\text { or Subcontractor between 1st } \\
\text { January ...... a and Bid submission } \\
\text { deadline, experience in managing } \\
\text { EHS risks and impacts in the } \\
\text { following aspects: }{ }^{\text {b }}\end{array}$ & Must meet requirements & $\begin{array}{l}\text { One member must meet } \\
\text { requirements } \\
\text { Or } \\
\text { All members must meet } \\
\text { requirements }\end{array}$ & Form EXP - 3 \\
\hline
\end{tabular}

a Insert year.

b Based on the EHS assessment, specify, as appropriate, specific experience requirements to manage EHS aspects. 


\section{Organizational Environmental, Health and Safety System}

\subsection{Environmental, Health and Safety Certification}

\begin{tabular}{|c|c|c|c|}
\hline Criteria & \multicolumn{2}{|c|}{ Compliance Requirements } & Documents \\
\hline Requirement & $\begin{array}{c}\text { Single Entity or Its } \\
\text { Specialist Subcontractors }\end{array}$ & $\begin{array}{l}\text { Joint Venture } \\
\text { or Its Specialist } \\
\text { Subcontractors }\end{array}$ & $\begin{array}{c}\text { Submission } \\
\text { Requirements }\end{array}$ \\
\hline $\begin{array}{l}\text { Availability of a valid ISO } \\
\text { certification or internationally } \\
\text { recognized equivalent (equivalency } \\
\text { to be demonstrated by the Bidder), } \\
\text { and applicable to the worksite: }{ }^{\text {a, b }} \\
\text { 1....... } \\
2 . \ldots \ldots \\
3 . \ldots \ldots\end{array}$ & Must meet requirement & $\begin{array}{l}\text { One member must meet } \\
\text { requirements } \\
\qquad \text { Or } \\
\text { All members must meet } \\
\text { requirements }\end{array}$ & Form EXP - 4 \\
\hline
\end{tabular}

a Examples of certification that can be selected:

1 Quality management certificate ISO 9001

2 Environmental management certificate ISO 14001

3 Health and Safety management certificate ISO 45001

b According to the environmental, health and safety issues of the worksite and the type of competition planned (national or international), it can be decided to not to keep this criterion or only to ask for part of the certifications, specifically the one(s) corresponding to the main issue of the worksite management. 


\subsection{Environmental, Health and Safety Documentation}

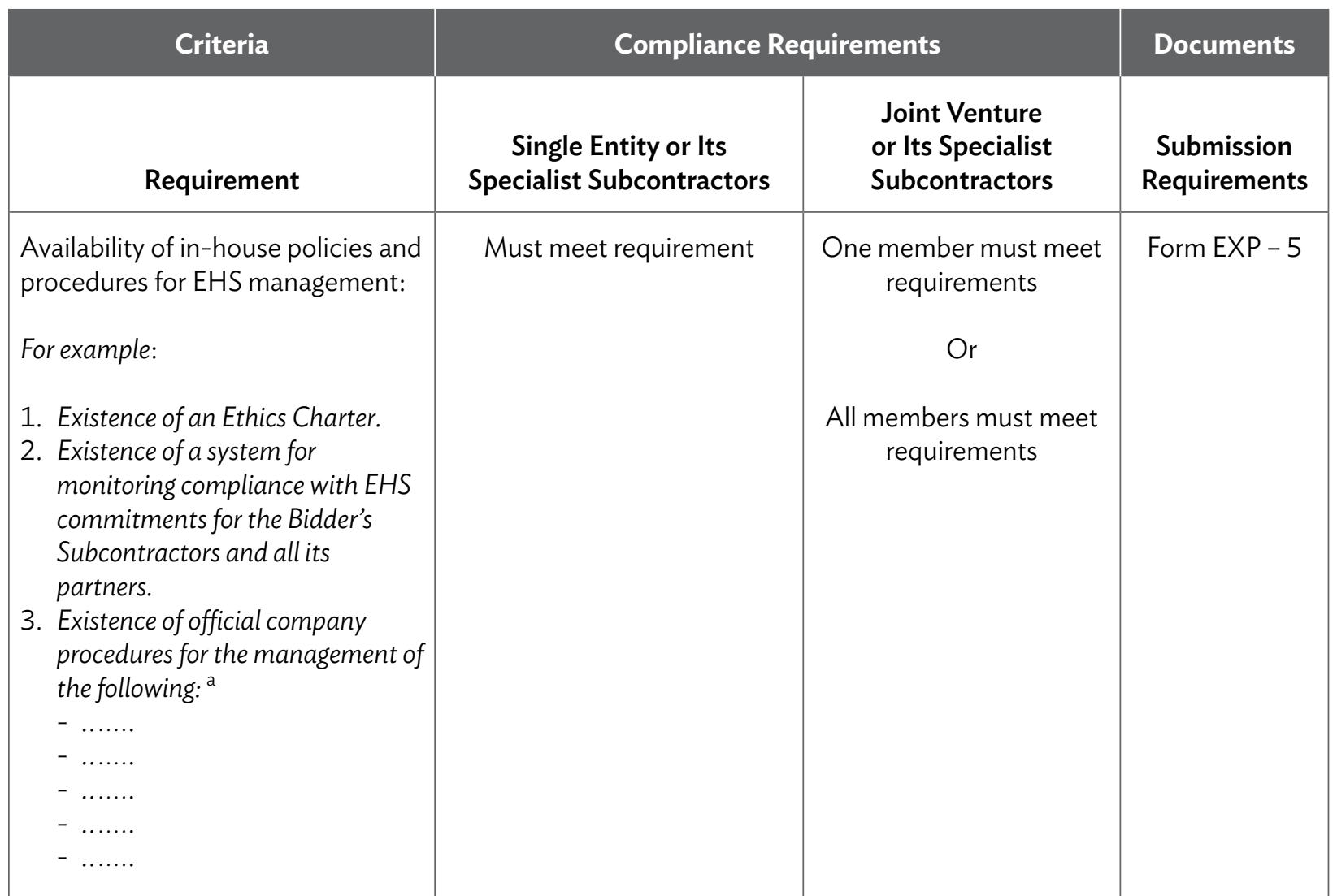

a From the below options, the Employer to select 3-5 that apply to the worksite. The selection should be based on the most pressing EHS issues pertaining to the worksite as detailed in the project EMP.

- EHS resources and facilities and EHS monitoring system;

- Project Areas management information (base camps, quarries, burrow pits, storage areas);

- Health and Safety on worksites policy and related guidance;

- Local recruitment and EHS trainings of local staff/subcontractors/local partners;

- Community stakeholder engagement practice;

- Traffic management practice;

- Hazardous products management practice;

- Waste management practice;

- Protection of water resources;

- Biodiversity protection practices;

- Site rehabilitation and revegetation practice;

- Local cultural heritage protection practice;

- Erosion and sedimentation practices;

- Control of infectious and communicable diseases (HIV/AIDS, malaria, COVID-19 etc) 
5.3 Environmental, Health and Safety Dedicated Personnel

\begin{tabular}{|l|c|c|c|}
\hline \multicolumn{1}{|c|}{ Criteria } & \multicolumn{2}{|c|}{ Compliance Requirements } & Documents \\
\hline \multicolumn{1}{|c|}{ Requirement } & $\begin{array}{c}\text { Single Entity or Its } \\
\text { Specialist Subcontractors }\end{array}$ & $\begin{array}{c}\text { Joint Venture } \\
\text { or Its Specialist } \\
\text { Subcontractors }\end{array}$ & $\begin{array}{c}\text { Submission } \\
\text { Requirements }\end{array}$ \\
\hline $\begin{array}{l}\text { Availability of in-house personnel } \\
\text { dedicated to EHS issues: } \\
- \text { - Environmental Specialist } \\
\text { - Health and Safety Specialist }\end{array}$ & Must meet requirement & $\begin{array}{c}\text { One member must meet } \\
\text { requirements }\end{array}$ & Form EXP-6 \\
& Or & $\begin{array}{c}\text { All members must meet } \\
\text { requirements }\end{array}$ & \\
\hline
\end{tabular}




\section{Section 4: Application Forms}

The Employer must include in Section 4 (Application Forms) all forms that the Applicant must complete and submit together with the Application.

\section{Table of Forms}

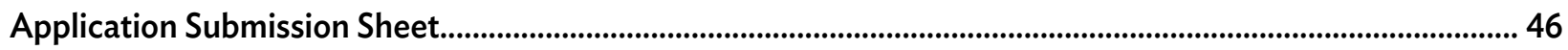

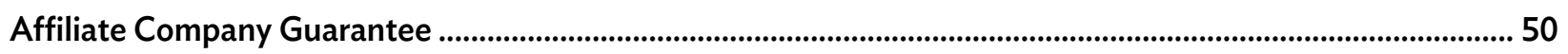

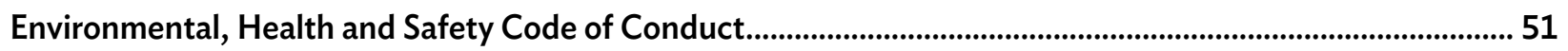

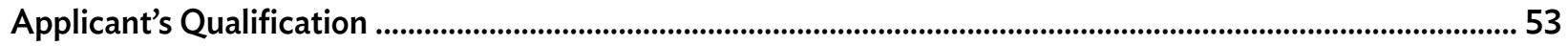

Form ELI - 1: Applicant Information Sheet ............................................................................................................. 54

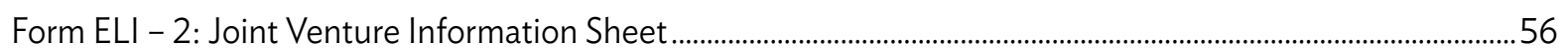

Form CON - 1: Historical Contract Nonperformance......................................................................................................... 58

Form CON - 2: EHS Performance Declaration ................................................................................................................ 60

Form FIN - 1: Historical Financial Performance ......................................................................................................62

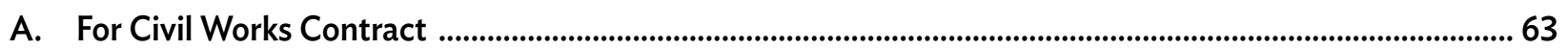

Form FIN - 2: Average Annual Construction Turnover .............................................................................................63

B. For Plant - Design, Supply, and Installation Contract ........................................................................................ 64

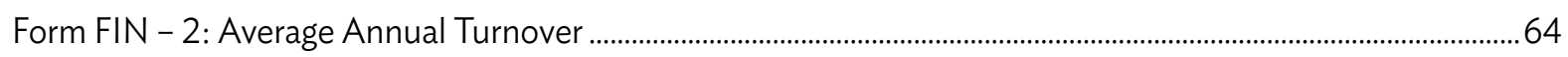

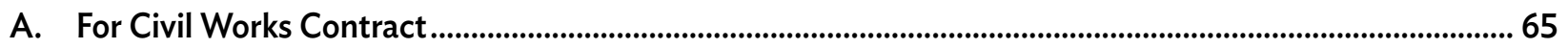

Form EXP - 1: Experience in Contracts of Similar Size and Nature..............................................................................65

Form EXP - 2: Construction Experience in Key Activities ..........................................................................................6

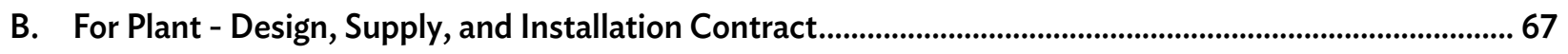

Form EXP - 1: Experience in Contracts of Similar Size and Nature...............................................................................67

Form EXP - 2: Experience in Key Activities ............................................................................................................ 68

Applicable for Civil Works Contract and for Plant Contract

Form EXP - 3: Specific Experience in Managing Environmental, Health and Safety Aspects ..............................69

Form EXP - 4: Environmental, Health and Safety Certification ..................................................................................... 70

Form EXP - 5: Environmental, Health and Safety Documentation.............................................................................. 70

Form EXP - 6: Environmental, Health and Safety Dedicated Personnel..................................................................... 70 


\section{Application Submission Sheet}

\section{NOTE}

The Applicant must accomplish the Application Submission Sheet in its letterhead clearly showing the Applicant's complete name and address.

Date:

IFP No.:

OCB No.:

To: [insert complete name of Employer]

We, the undersigned, apply to be prequalified for the referenced $O C B$ and declare the following.

(a) We have examined and have no reservations to the Prequalification Document, including addenda, issued in accordance with ITA 8.

(b) We acknowledge that we have read and understand ADB's Anticorruption Policy (1998) and Integrity Principles and Guidelines (2015), both as amended from time to time.

(c) We, including any Subcontractors or Suppliers for any part of the contract resulting from this prequalification process, if any, have nationalities from eligible countries, in accordance with ITA 4.2.

(d) We, our directors, key officers, key personnel, including any Subcontractors, consultants, subconsultants, manufacturers, service providers or Suppliers for any part of the contract resulting from this prequalification process, if any, do not have any conflict of interest in accordance with ITA 4.3 and 4.4.

If there is any conflict of interest, please state details:

(i) Parties involved in the conflict of interest:

(ii) Details about the conflict of interest:

(e) Our firm, Joint Venture partners, our respective direct and indirect shareholders, directors, key officers, key personnel, associates, parent company, affiliates or subsidiaries, including any Subcontractors, consultants, subconsultants, manufacturers, service providers or Suppliers for any part of the contract, are not subject to, or not controlled by any entity or individual that is subject to, a temporary suspension or a debarment imposed by the Asian Development Bank or a debarment imposed by the Asian Development Bank in accordance with the Agreement for Mutual Enforcement of Debarment Decisions between the Asian Development Bank and other development banks. ${ }^{1}$

1 These institutions include African Development Bank, European Bank for Reconstruction and Development (EBRD), InterAmerican Development Bank (IADB), and the World Bank Group. According to para. 9 of the Agreement, other international financial institutions may join upon the consent of all Participating Institutions and signature of a Letter of Adherence by the international financial institution substantially in the form provided (Annex B to the Agreement). Upon adherence, such international financial institution shall become a Participating Institution for purposes of the Agreement. Bidders are advised to check www.adb.org/integrity for updates. 
(f) Our firm, Joint Venture partners, our respective direct and indirect shareholders, directors, key officers, key personnel, associates, parent company, affiliates or subsidiaries, including any Subcontractors, consultants, subconsultants, manufacturers, service providers or Suppliers for any part of the contract, are not under ongoing investigation and/or sanctions proceedings by the Asian Development Bank or any multilateral development bank.

If under ongoing investigation and/or sanction proceedings by the Asian Development Bank or any multilateral development bank, please state details:

(i) Name of the multilateral development bank:

(ii) Reason for the ongoing investigation / allegations:

(g) Our firm, Joint Venture partners, our respective direct and indirect shareholders, directors, key officers, key personnel, associates, parent company, affiliates or subsidiaries, including any Subcontractors, consultants, subconsultants, manufacturers, service providers or Suppliers for any part of the Contract, are not temporarily suspended, debarred, declared ineligible, or subject to any national and/or international sanctions by any country, any international organization, any multilateral development bank and other donor agency.

If so temporarily suspended, debarred, declared ineligible, or subject to any national and/or international sanctions by any country, any international organization, any multilateral development bank and other donor agency, please state details (as applicable to each Joint Venture partner, their respective direct or indirect shareholders, directors, key officers, key personnel, associate, parent company, affiliate, subsidiaries, Subcontractors, consultants, subconsultants, manufacturers, service providers and/or Suppliers):

(i) Name of institution:

(ii) Period of the temporary suspension, debarment, ineligibility, or national or international sanction [start and end date]:

(iii) Reason for the temporary suspension, debarment, ineligibility, or national or international sanction:

(h) Our firm, Joint Venture partners, associates, parent company, affiliates or subsidiaries, including any Subcontractors, consultants, subconsultants, manufacturers, service providers, Suppliers, key officers, directors, and key personnel have never been charged or convicted with any criminal offense (including felonies but excluding misdemeanors) or infractions and/or violations of ordinance; nor charged or found liable in any civil or administrative proceedings in the last 10 years; or undergoing investigation for such, or subject to any criminal, civil or administrative orders, monitorship or enforcement actions..

If so charged, convicted/found liable, under ongoing investigation, or subject to orders, monitorship or enforcement actions, please state details:

(i) Nature of the offense, violation, proceedings, investigation, and/or monitorship or enforcement actions:

(ii) Court, area of jurisdiction and/or the enforcement agency:

(iii) Resolution [i.e. dismissed, settled, or convicted; duration of penalty]:

(iv) Other relevant details [please specify]:

(i) Our firm, Joint Venture partners, our respective direct and indirect shareholders, directors, key officers, key personnel, associates, affiliates or subsidiaries, including any Subcontractors, consultants, subconsultants, manufacturers, service providers or Suppliers, can make and receive electronic fund transfer payments through the international banking system or otherwise discharge the Employer's obligation upon initiation of wire transfer. 
If unable to make or receive funds through the international banking system or otherwise discharge the Employer's obligation upon initiation of wire transfer, please state the details:

(i) Nature of the restriction:

(ii) Jurisdiction of the restriction:

(iii) Other relevant details:

(j) Our firm, Joint Venture partners, associates, parent company, affiliates or subsidiaries, including any Subcontractors, consultants, subconsultants, manufacturers, service providers or Suppliers, key officers, directors and key personnel are not from a country which is prohibited to export goods or services to, or receive any payments from the Employer's country and/or are not prohibited to receive payments for particular goods or services by the Employer's country by an act of compliance with a decision of the United Nations Security Council taken under Chapter VII of the Charter of the United Nations.

(k) We understand that it is our obligation to notify the Employer of any changes in connection with the matters described in paragraphs (e), (f), (g), (h), (i), (j) and (n) of this Application Submission Sheet.

(I) [We are not a government-owned enterprise] / [We are a government-owned enterprise but meet the requirements of ITA 4.6]. ${ }^{2}$

(m) We, in accordance with ITA 24.1, plan to subcontract the following key activities or parts of the contract:

(n) We have paid, or intend to pay, either directly or indirectly, the following commissions, gratuities, or fees with respect to the prequalification process: ${ }^{3}$

Name of Recipient

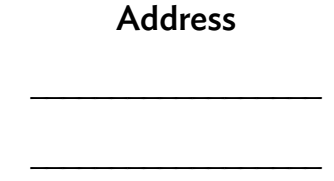

Reason

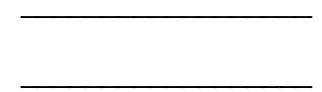

\section{Amount}

(o) We understand that you may cancel the prequalification process at any time and that you are not bound either to accept any Application that you may receive or to invite the prequalified Applicants to bid for the contract subject of this prequalification, without incurring any liability to the Applicants, in accordance with ITA 26.

(p) At any time following submission of our Application, we shall permit, and shall cause our Joint Venture partners, directors, key officers, key personnel, associates, parent company, affiliates or subsidiaries, including any Subcontractors, consultants, subconsultants, manufacturers, service providers or Suppliers for any part of the contract to permit ADB or its representative to inspect our site, assets, accounts and records and other documents relating to the Application for prequalification and to have them audited by auditors appointed by $A D B$. We understand that failure of this obligation may constitute obstructive practice that may result in debarment and/or contract termination.

(q) Regardless of whether the contract will be awarded to us, we shall preserve all accounts, records and other documents related to application submission for at least 3 years from the date of submission of the application or the period prescribed in applicable law, whichever is longer.

Use one of the two options as appropriate.

If none has been paid or is to be paid, indicate "None." 
(r) If we are awarded the contract, we shall preserve all accounts, records and other documents related to the procurement and execution of the contract for at least 5 years after completing the works contemplated in the relevant contracts or the period prescribed in applicable law, whichever is longer.

(s) We certify on behalf of the Applicant, that the information provided in the bid has been fully reviewed, given in good faith, and to the best of our knowledge is true and complete. We understand that it is our obligation to inform the Employer of any changes to the information as and when it becomes known to us. We understand that any misrepresentation that knowingly or recklessly misleads, or attempts to mislead may lead to the automatic rejection of the Application for prequalification, or the Bid or cancellation of the contract, if awarded; and may result in remedial actions, in accordance with ADB's Anticorruption Policy (1998, as amended to date) and Integrity Principles and Guidelines (2015, as amended from time to time).

Name: [insert complete name of the person signing the application]

In the capacity of [insert legal capacity of the person signing the application]

Signed: [insert signature of the person whose name and capacity are shown above]

Duly authorized to sign the Application for and on behalf of [insert complete name of the applicant]

Date: [insert date of signing] 


\section{Affiliate Company Guarantee}

Name of Contract/Contract No.:

Name and address of Employer:

[together with successors and assigns].

We have been informed that [name of Applicant] (hereinafter called the "Contractor") is submitting an offer for the above-referenced Contract in response to your invitation, and that the conditions of your invitation require its offer to be supported by an affiliate company guarantee.

In consideration of you, the Employer, awarding the Contract to the Contractor, we [name of affiliated company] irrevocably and unconditionally guarantee to you, as a primary obligation, that (i) throughout the duration of the Contract, we will make available to the Contractor our financial, technical capacity, expertise and resources required for the Contractor's satisfactory performance of the Contract; and (ii) we are fully committed, along with the Contractor, to ensuring a satisfactory performance of the Contract.

If the Contractor fails to so perform its obligations and liabilities and comply with the Contract, we will indemnify the Employer against and from all damages, losses and expenses (including legal fees and expenses) which arise from any such failure for which the Contractor is liable to the Employer under the Contract.

This guarantee shall come into full force and effect when the Contract comes into full force and effect. If the Contract does not come into full force and effect within a year of the date of this guarantee, or if you demonstrate that you do not intend to enter into the Contract with the Contractor, this guarantee shall be void and ineffective. This guarantee shall continue in full force and effect until all the Contractor's obligations and liabilities under the Contract have been discharged, when this guarantee shall expire and shall be returned to us, and our liability hereunder shall be discharged absolutely.

This guarantee shall apply and be supplemental to the Contract as amended or varied by the Employer and the Contractor from time to time. We hereby authorize them to agree on any such amendment or variation, the due performance of which and compliance with which by the Contractor are likewise guaranteed hereunder. Our obligations and liabilities under this guarantee shall not be discharged by any allowance of time or other indulgence whatsoever by the Employer to the Contractor, or by any variation or suspension of the works to be executed under the Contract, or by any amendments to the Contract or to the constitution of the Contractor or the Employer, or by any other matters, whether with or without our knowledge or consent.

This guarantee shall be governed by the law of the same country (or other jurisdiction) that governs the Contract and any dispute under this guarantee shall be finally settled under the [Rules or Arbitration provided in the Contract]. We confirm that the benefit of this guarantee may be assigned subject only to the provisions for assignment of the Contract.

Signed by:

[signature]

[name]

[position in parent or subsidiary company]
Signed by:

[signature]

[name]

[position in parent or subsidiary company]

Date:

\section{NOTE}

If permitted in accordance with ITA 25.4 of the ADS, the Applicant shall provide the Affiliate Company Guarantee Form filled out and signed by each subsidiary, parent entity, or affiliate. that the Applicant submits for consideration of the Employer in determining its qualifications. 
Environmental, Health and Safety Code of Conduct

\section{Environmental, Health and Safety Code of Conduct for Contractor's Personnel Form}

\section{NOTE TO EMPLOYER}

The following minimum requirements shall not be modified. The Employer may add additional requirements to address identified issues, informed by relevant environmental, health and safety assessment.

Delete this Box prior to issuance of the bidding documents.

\section{NOTE TO BIDDER}

The minimum content of the EHS Code of Conduct form as set out by the Employer shall not be substantially modified. However, the Bidder may add requirements as appropriate, including to take into account Contract-specific issues/risks.

The Bidder shall initial and submit the EHS Code of Conduct form as part of its bid.

\section{ENVIRONMENTAL, HEALTH AND SAFETY CODE OF CONDUCT FOR CONTRACTOR'S PERSONNEL}

We are the Contractor, [enter name of Contractor]. We have signed a contract with [enter name of Employer] for [enter description of the Works]. These Works will be carried out at [enter the Site and other locations where the Works will be carried out]. Our contract requires us to implement measures to address environmental, health and safety risks related to the Works.

This EHS Code of Conduct is part of our measures to deal with environmental, health and safety risks related to the Works. It applies to all our staff, labourers and other employees at the Works Site or other places where the Works are being carried out. It also applies to the personnel of each subcontractor and any other personnel assisting us in the execution of the Works. All such persons are referred to as "Contractor's Personnel" and are subject to this EHS Code of Conduct.

This EHS Code of Conduct identifies the behavior that we require from all Contractor's Personnel.

Our workplace is an environment where unsafe, offensive, abusive or violent behavior will not be tolerated and where all persons should feel comfortable raising issues or concerns without fear of retaliation.

\section{REQUIRED CONDUCT}

Contractor's Personnel shall:

1. carry out his/her duties competently and diligently;

2. comply with this EHS Code of Conduct and all applicable laws, regulations and other requirements, including requirements to protect the health, safety and well-being of other Contractor's Personnel and any other person;

3. maintain a safe working environment including by:
a. ensuring that workplaces, machinery, equipment and processes under each person's control are safe and without risk to health;
b. wearing required personal protective equipment; 
c. using appropriate measures relating to chemical, physical and biological substances and agents; and

d. following applicable emergency operating procedures.

4. report work situations that he/she believes are not safe or healthy and remove himself/herself from a work situation which he/she reasonably believes presents an imminent and serious danger to his/her life or health;

5. treat other people with respect, and not discriminate against specific groups such as women, people with disabilities, migrant workers or children;

6. report violations of this EHS Code of Conduct; and

7. not retaliate against any person who reports violations of this EHS Code of Conduct, whether to us or the Employer, or who makes use of the grievance mechanism for Contractor's Personnel or the project's Grievance Redress Mechanism.

\section{RAISING CONCERNS}

If any person observes behavior that he/she believes may represent a violation of this EHS Code of Conduct, or that otherwise concerns him/her, he/she should raise the issue promptly. This can be do done by call [ ] to reach the Contractor's hotline (if any) and leave a message.

The person's identity will be kept confidential, unless reporting of allegations is mandated by the country law. Anonymous complaints or allegations may also be submitted and will be given all due and appropriate consideration. We take seriously all reports of possible misconduct and will investigate and take appropriate action. We will provide warm referrals to service providers that may help support the person who experienced the alleged incident, as appropriate.

\section{CONSEQUENCES OF VIOLATING THE ENVIRONMENTAL, HEALTH AND SAFETY CODE OF CONDUCT}

Any violation of this EHS Code of Conduct by Contractor's Personnel may result in serious consequences, up to and including termination and possible referral to legal authorities.

\section{FOR CONTRACTOR'S PERSONNEL:}

I have received a copy of this EHS Code of Conduct written in a language that I comprehend. I understand that if I have any questions about this EHS Code of Conduct, I can contact [enter name of Contractor's contact person(s) with relevant experience)] requesting an explanation.

Name of Contractor's Personnel: [insert name]

Signature:

Date: (day month year):

Countersignature of authorized representative of the Contractor:

Signature:

Date: (day month year): 


\section{Applicant's Qualification}

To establish its qualifications to perform the contract in accordance with Section 3 (Qualification Criteria) the Applicant shall provide the following information requested in the corresponding Information Sheets. 
Form ELI - 1: Applicant Information Sheet

Date:

IFP No.:

OCB No.:

Page ..of pages

\begin{tabular}{|c|c|c|c|}
\hline \multicolumn{4}{|c|}{ Applicant Information } \\
\hline & & Information of the Applicant & $\begin{array}{l}\text { If the Applicant is a subsidiary } \\
\text { or branch, information of any } \\
\text { parent company/companies }\end{array}$ \\
\hline \multirow[b]{2}{*}{ Names } & Full legal name(s) & & \\
\hline & $\begin{array}{l}\text { Full trading name(s) } \\
\text { (if any) }\end{array}$ & & \\
\hline \multirow{3}{*}{ Addresses } & $\begin{array}{l}\text { Registered } \\
\text { address(es) }\end{array}$ & & \\
\hline & Trading address(es) & & \\
\hline & $\begin{array}{l}\text { Postal address(es) } \\
\text { (if different from } \\
\text { trading address) }\end{array}$ & & \\
\hline \multicolumn{2}{|c|}{ Type of organization } & & \\
\hline \multicolumn{2}{|c|}{$\begin{array}{l}\text { Country of constitution/incorporation/ } \\
\text { registration }\end{array}$} & & \\
\hline \multicolumn{2}{|c|}{$\begin{array}{l}\text { Year of constitution/incorporation/ } \\
\text { registration }\end{array}$} & & \\
\hline \multicolumn{2}{|c|}{ Corporate or registration number } & & \\
\hline \multicolumn{2}{|c|}{$\begin{array}{l}\text { In case of a Joint Venture, legal name of } \\
\text { each partner }\end{array}$} & & \\
\hline
\end{tabular}


Applicant's authorized representative

(name, address, telephone number(s), fax number(s), e-mail address)

\section{Attached are copies of the following documents:}

1. In case of a single entity, articles of incorporation or constitution and company incorporation/registration of the legal entity named above, in accordance with ITA 4.1 and ITA 4.2.

2. Authorization to represent the firm or Joint Venture named above, in accordance with ITA 15.3.

3. In case of a Joint Venture, a letter of intent to form a Joint Venture or Joint Venture agreement, in accordance with ITA 4.1.

4. In case of a government-owned enterprise, any additional documents not covered under 1 above required to comply with ITA 4.6. 
Form ELI - 2: Joint Venture Information Sheet

Date:

IFP No.:

OCB No.:

Page .of

Each partner of the Joint Venture and Specialist Subcontractor, if any, must fill out this form separately.

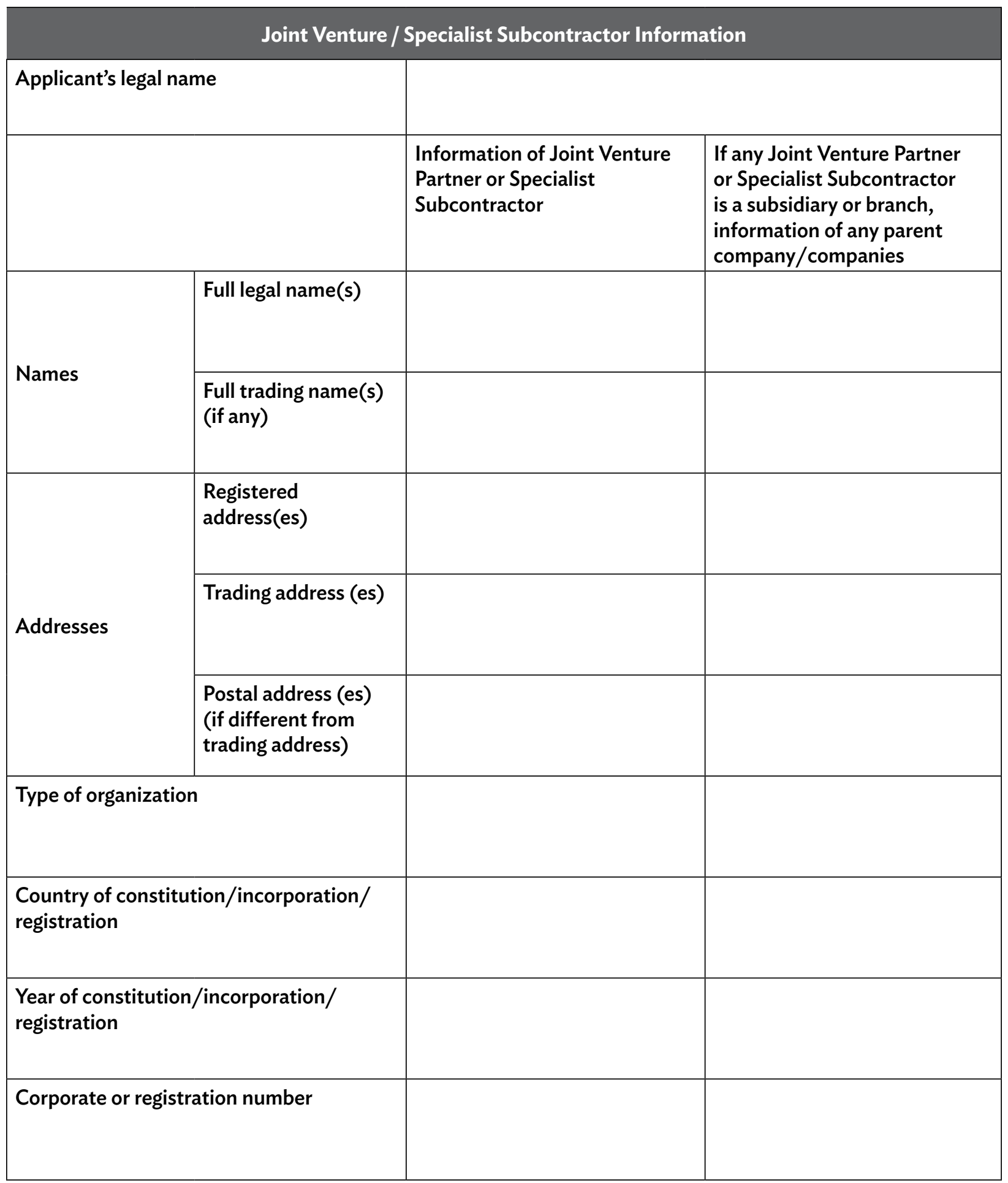


Joint Venture Partner's or Specialist

Subcontractor's authorized

representative information

(name, address, telephone number(s),

fax number(s), e-mail address)

\section{Attached are copies of the following documents:}

1. Articles of incorporation or constitution and company incorporation/registration of the legal entity named above, in accordance with ITA 4.1 and ITA 4.2.

2. Authorization to represent the firm named above, in accordance with ITA 15.3.

3. In the case of a government-owned enterprise, documents establishing legal and financial autonomy and compliance with commercial law, in accordance with ITA 4.6.

4. In case of Specialist Subcontractors as per ITA 24.2 a formal intent to enter into an agreement in the form of a letter jointly signed by the Applicant and the Specialist Subcontractor. 


\section{Form CON - 1: Historical Contract Nonperformance}

Date:

IFP No.:

OCB No.:

Page

.of pages

Each Applicant must fill out this form in accordance with Criteria 2.1 and 2.2 of Section 3 (Qualification Criteria) to describe any history of nonperforming contracts and pending litigation or arbitration formally commenced against it.

In case of a Joint Venture, each Joint Venture Partner must fill out this form separately and provide the Joint Venture Partner's name:

Joint Venture Partner:

\section{Table 1: History of Nonperforming Contracts}

\section{Choose one of the following:}

$\square \quad$ No nonperforming contracts.

$\square$ Below is a description of nonperforming contracts involving the Applicant (or each Joint Venture partner if Applicant is a Joint Venture).

\begin{tabular}{|c|l|c|c|}
\hline Year & \multicolumn{1}{|c|}{$\begin{array}{r}\text { Amount of } \\
\text { Description }\end{array}$} & $\begin{array}{r}\text { Norformed Portion } \\
\text { of Contract } \\
\text { (\$ equivalent) }\end{array}$ & $\begin{array}{c}\text { Total Contract Amount } \\
\text { (\$ equivalent) }\end{array}$ \\
\hline [insert year] & $\begin{array}{l}\text { Contract Identification: [indicate complete } \\
\text { contract name/ number, and any other } \\
\text { identification] } \\
\text { Name of Employer: [insert full name] }\end{array}$ & $\begin{array}{l}\text { [insert amount] } \\
\text { Address of Employer: [insert street/city/ } \\
\text { country] } \\
\text { Reason(s) for nonperformance: [indicate main } \\
\text { reason(s)] }\end{array}$ & \\
\hline
\end{tabular}




\section{Table 2: Pending Litigation and Arbitration}

\section{Choose one of the following:}

$\square$ No pending litigation, arbitration or any other material events impacting the net worth and/or liquidity of the applicant.

$\square$ Below is a description of all pending litigation, arbitration involving the Applicant or any other material events impacting the net worth and/or liquidity of the applicant (or each Joint Venture partner if Applicant is a Joint Venture).

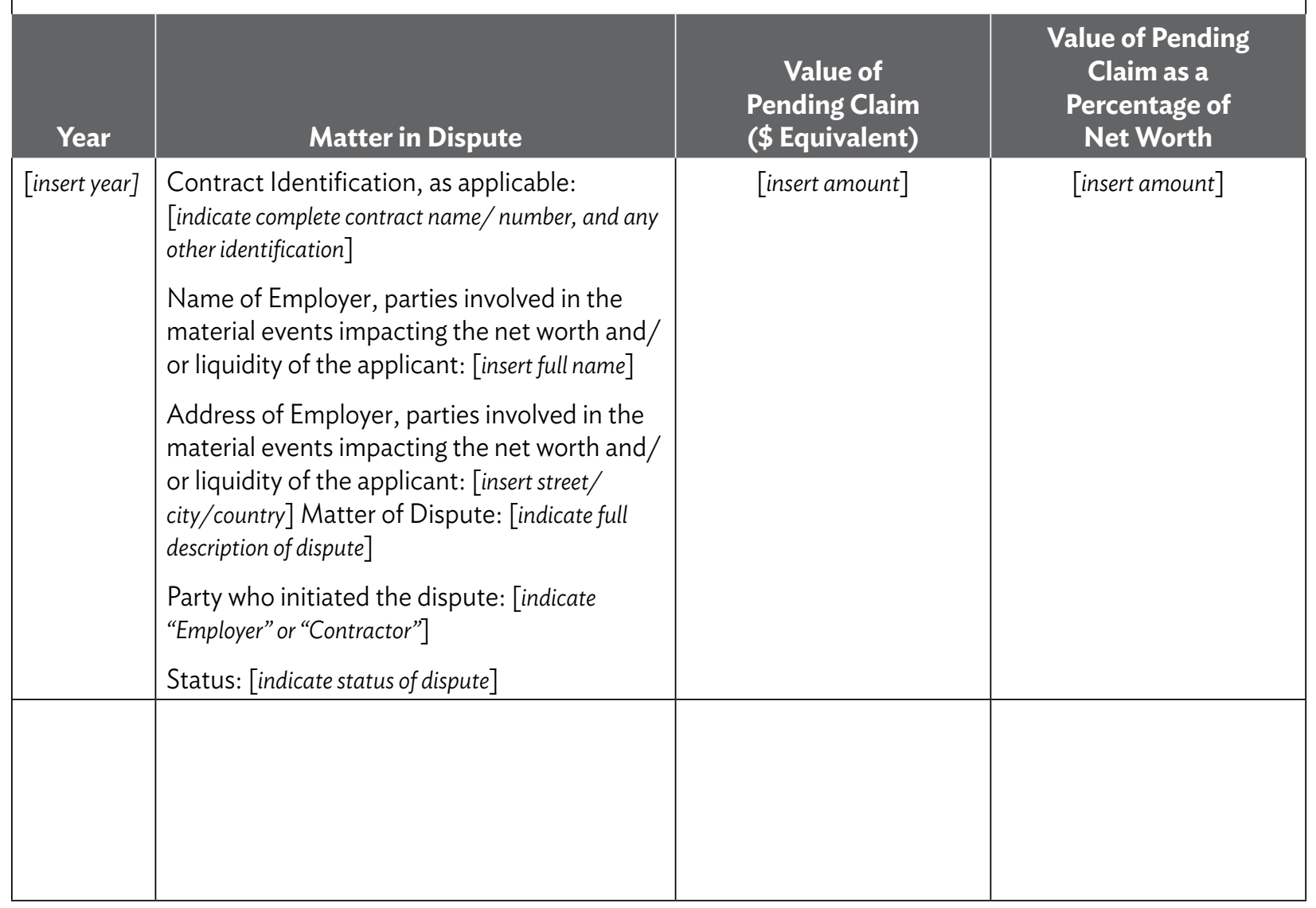

\section{NOTE}

Table 2 of this form shall only be included if Criterion 2.2 of Section 3 (Qualification Criteria) is applicable. 


\section{Form CON - 2: EHS Performance Declaration}

Each Applicant must fill out this form in accordance with Criterion 2.3 of Section 3 (Qualification Criteria).

In case of a Joint Venture, each Joint Venture Partner must fill out this form separately and provide the Joint Venture Partner's name:

Joint Venture Partner:

In case of a Specialist Subcontractors, each Specialist Subcontractor must fill out this form and provide the Specialist Subcontractor's name:

Specialist Subcontractor:

\section{Environmental and Health and Safety Performance Declaration in accordance with Section 3 (Qualification Criteria)}

$\square$ No suspension or termination of contract: An employer has not suspended or terminated a contract and/ or called the performance security for a contract for reasons related to Environmental or Health and Safety performance since the date specified in Criterion 2.5 of Section 3 (Evaluation and Qualification Criteria).

$\square$ Declaration of suspension or termination of contract: The following contract(s) has/have been suspended or terminated and/or Performance Security called by an employer(s) for reasons related to Environmental or Health and Safety performance since the date specified in Criterion 2.5 of Section 3 (Evaluation and Qualification Criteria). Details are described below:

$\square$ Declaration of request for replacement of Key Environment, Health and Safety Personnel: The following contract(s) has/have experienced a request by the Employer to replace Environmental, Health and Safety Personnel for reasons related to Environmental or Health and Safety performance since the date specified in Criterion 2.5 of Section 3 (Evaluation and Qualification Criteria). Details are described below:

$\square$ Declaration of past fatality resulted from EHS issues on site: The following contract(s) has/have experienced a fatality resulted from EHS issues on site since the date specified in Criterion 2.5 of Section 3 (Evaluation and Qualification Criteria). Details are described below:

\begin{tabular}{|c|c|c|c|}
\hline Year & $\begin{array}{l}\text { Suspended or } \\
\text { terminated } \\
\text { portion of } \\
\text { contract }\end{array}$ & Contract Identification & $\begin{array}{l}\text { Total Contract } \\
\text { Amount (current } \\
\text { value, currency, } \\
\text { exchange } \\
\text { rate and US\$ } \\
\text { equivalent) }\end{array}$ \\
\hline [insert year] & $\begin{array}{l}\text { [insert amount and } \\
\text { percentage] }\end{array}$ & $\begin{array}{l}\text { Contract Identification: [indicate complete contract name/ } \\
\text { number, and any other identification] } \\
\text { Name of Employer: [insert full name] } \\
\text { Address of Employer: [insert street/city/country] } \\
\text { Reason(s) for suspension or termination: [indicate main } \\
\text { reason(s) e.g. discharge over environmental limit, workers did not have } \\
\text { required health and safety permits to undertake high risk work, work } \\
\text { carried out was not adhered to approved construction methodology } \\
\text { and quality control plan.] }\end{array}$ & [insert amount] \\
\hline [insert year] & $\begin{array}{l}\text { [insert amount and } \\
\text { percentage] }\end{array}$ & $\begin{array}{l}\text { Contract Identification: [indicate complete contract name/ } \\
\text { number, and any other identification] } \\
\text { Name of Employer: [insert full name] } \\
\text { Address of Employer: [insert street/city/country] } \\
\text { Reason(s) for suspension or termination: [indicate main } \\
\text { reason(s)] }\end{array}$ & [insert amount] \\
\hline & .. & [list all applicable contracts] & .. \\
\hline
\end{tabular}




\begin{tabular}{|l|l|c|}
\hline \multicolumn{3}{|c|}{ Performance Security called by an employer(s) for reasons related to EHS performance } \\
\hline Year & Contract Identification & $\begin{array}{l}\text { Total Contract } \\
\text { Amount (current } \\
\text { value, currency, } \\
\text { exchange rate and } \\
\text { US\$ equivalent) }\end{array}$ \\
\hline [insert year] & $\begin{array}{l}\text { Contract Identification: [indicate complete contract name/ number, and any other } \\
\text { identification] } \\
\text { Name of Employer: [insert full name] } \\
\text { Address of Employer: [insert street/city/country] } \\
\text { Reason(s) for calling of performance security: [indicate main reason(s) e.g. discharge } \\
\text { over environmental limit, workers did not have required health and safety permits to } \\
\text { undertake high risk work, work carried out was not adhered to approved construction } \\
\text { methodology and quality control plan.] }\end{array}$ & {$\left[\begin{array}{c}\text { insert } \\
\end{array}\right.$} \\
\hline
\end{tabular}

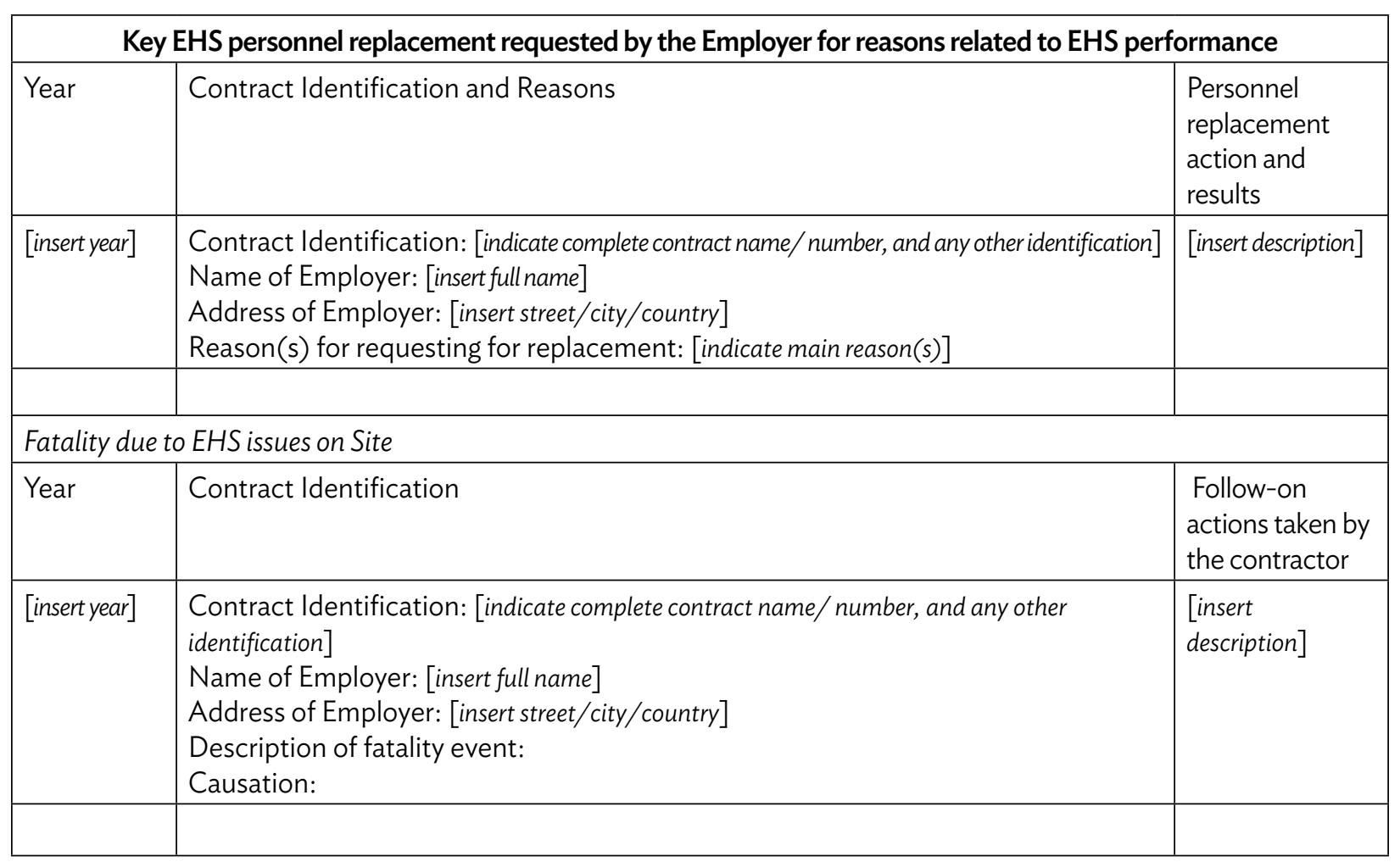


Form FIN - 1: Historical Financial Performance

Date:

IFP No.:

OCB No.:

Page

of pages

Each Applicant must fill out this form.

In case of a Joint Venture, each Joint Venture Partner must fill out this form separately and provide the Joint Venture Partner's name:

Joint Venture Partner:

Financial Data for Previous 3 Years ${ }^{a}$ [\$ Equivalent]

\begin{tabular}{l|l|l} 
Year 1: & Year 2: & Year 3: \\
\cline { 1 - 2 } & &
\end{tabular}

Information from Balance Sheet

\begin{tabular}{|l|l|l|l|}
\hline Total Assets (TA) & & & \\
\hline Total Liabilities (TL) & & & \\
\hline Net Worth = TA - TL & & & \\
\hline Current Assets (CA) & & & \\
\hline Current Liabilities (CL) & & & \\
\hline Working Capital = CA - CL & & & \\
\hline
\end{tabular}

\begin{tabular}{|l|l|l|l|}
\hline Most Recent Working Capital & & & \\
\hline \multicolumn{2}{|c|}{ Information from Income Statement } & \\
\hline Total Revenues & & & \\
\hline Profits Before Taxes & & & \\
\hline Profits After Taxes & & & \\
\hline
\end{tabular}

$\square \quad$ Attached are copies of financial statements (balance sheets including all related notes and income statements) for the last 3 years, ${ }^{b}$ as indicated above, complying with the following conditions:

1) Unless otherwise required by Section 3 (Qualification Criteria), all such documents must reflect the standalone financial situation of the legal entity or entities comprising the Applicant and not the Applicant's parent companies, subsidiaries, or affiliates. ${ }^{c}$

2) Historical financial statements must be audited by a certified accountant.

3) Historical financial statements must be complete, including all notes to the financial statements.

4) Historical financial statements must correspond to accounting periods already completed and audited (no statements for partial periods shall be accepted).

a If the time period indicated under Criterion 3.1 of Section 3 (Qualification Criteria) is either 4 or 5 years, then the table columns above should be expanded accordingly.

${ }^{b}$ The time period stated here should be the same as the time period indicated under Criterion 3.1 of Section 3 (Qualification Criteria).

c When financial qualifications of Applicant's parent companies, subsidiaries, or affiliates are permitted in accordance with ITA 25.4 of the ADS, replace the text of condition 1 with "As required by Section 3 of the Prequalification Documents, all such documents reflect the standalone financial situation of the legal entity or entities comprising the Applicant, as well as standalone financial situation of such Applicant's parent companies, subsidiaries, or affiliates which are proposed by the Applicant for Criterion 3.1 Financial Situation in Section 3 for consideration of the Employer in determining its qualifications." 


\section{A. For Civil Works Contract}

\section{Form FIN - 2: Average Annual Construction Turnover}

Date:

IFPNo.:

OCB No.:

Page .

..of

pages

Each Applicant must fill out this form.

The information supplied should be the Annual Construction Turnover of the Applicant or each partner of a Joint Venture for the total certified payments received from the clients for contracts in progress or completed, converted to US dollars at the rate of exchange at the end of the period reported.

In case of a Joint Venture, each Joint Venture Partner must fill out this form separately and provide the Joint Venture Partner's name:

Joint Venture Partner:

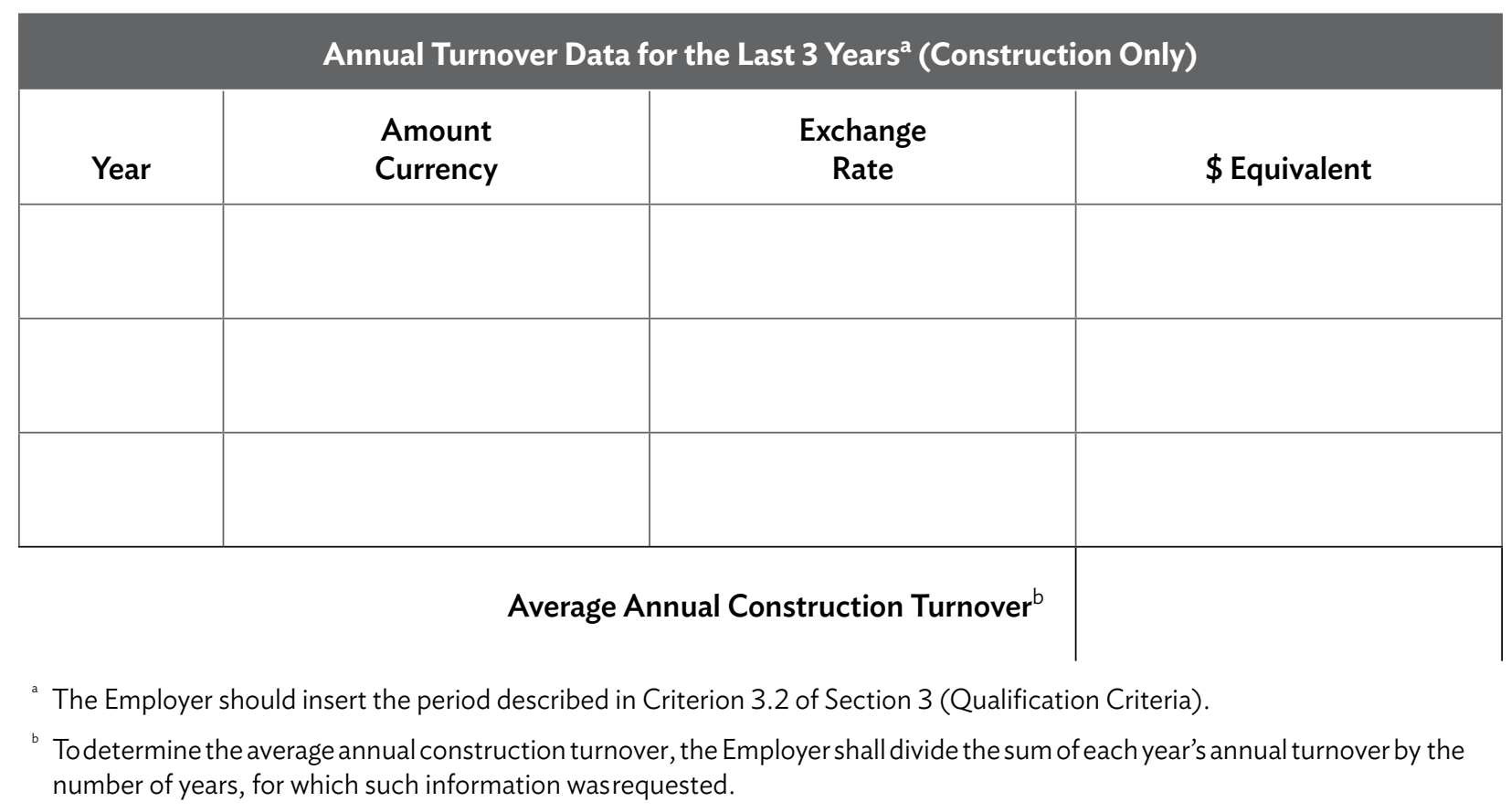




\section{B. For Plant - Design, Supply, and Installation Contract}

\section{Form FIN - 2: Average Annual Turnover}

Date:

IFPNo.:

OCB No.:

Page

of

pages

Each Applicant must fill out this form.

The information supplied should be the Annual Turnover of the Applicant or each partner of a Joint Venture for the total certified payments received from the clients for contracts in progress or completed, converted to US dollars at the rate of exchange at the end of the period reported.

In case of a Joint Venture, each Joint Venture Partner must fill out this form separately and provide the Joint Venture Partner's name:

Joint Venture Partner:

\begin{tabular}{|c|c|c|c|}
\hline \multirow{3}{*}{ Annual Turnover Data for the Last 3 Years } & \\
\hline & Amount & Exchange \\
Rate & & & \$ Equivalent \\
\hline & & & \\
\hline & & & \\
\hline & & & \\
\hline
\end{tabular}

a The Employer should insert the period described in Criterion 3.2 of Section 3 (Qualification Criteria).

b To determine the average annual turnover, the Employer shall divide the sum of each year's annual turnover by the number of years, for which such information was requested. 


\section{A. For Civil Works Contract}

\section{Form EXP - 1: Experience in Contracts of Similar Size and Nature}

Date:

IFPNo.:

OCB No.:

Page

.of

pages

Fill out one (1) form per contract. Each contract shall be supported by documents such as Signed Contract Agreement, Taking-Over Certificate, Contract Completion Certificate or Performance Certificate.

The exchange rate to be used to calculate the value of the contract for conversion to a specific currency shall be the selling rate of the Borrower's Central bank on the date of the contract.

\section{Contract of Similar Size and Nature}

\begin{tabular}{|l|l}
\hline Contract No..... of ....... & Contract Identification
\end{tabular}

\begin{tabular}{|l|l|l|}
\hline \multicolumn{2}{|l|}{ Award Date } & \multicolumn{2}{|l|}{ Completion Date } \\
\hline Total Contract Amount & $\$$ & \\
\hline $\begin{array}{l}\text { If partner in a Joint Venture } \\
\text { or Subcontractor, specify } \\
\text { participation of total contract } \\
\text { amount }\end{array}$ & Percent of Total & Amount \\
\hline $\begin{array}{l}\text { Employer's name } \\
\text { Address } \\
\text { Telephone number }\end{array}$ & $\begin{array}{l}\text { Fax number } \\
\text { E-mail }\end{array}$ & \\
\hline
\end{tabular}

\section{Description of the Similarity in Accordance with Criterion 4.1 of Section 3 (Qualification Criteria)}

\section{NOTE}

The Employer should insert here contract size, complexity, methods, technology, or other characteristics as described in Criterion 4.1 of Section 3 against which the Applicant should demonstrate similarity in the box on the right-hand side. 
Form EXP - 2: Construction Experience in Key Activities

Date:

IFP No.:

OCB No.:

Page

.of

pages

Fill out one (1) form per contract. Each contract shall be supported by documents such as Signed Contract Agreement, Taking-Over Certificate or Contract Completion Certificate.

Each Applicant must fill out this form.

If complied by Specialist Subcontractors, each Specialist Subcontractor must fill out this form and provide the Specialist Subcontractor's name:

Specialist Subcontractor:

\section{Contract with Similar Key Activities}

Contract No..... of ..... Contract Identification

\begin{tabular}{|l|l|}
\hline Award Date & Completion Date \\
\hline
\end{tabular}

\begin{tabular}{|l|l|l|}
\hline Total Contract Amount & $\$$ \\
\hline $\begin{array}{l}\text { If partner in a Joint Venture } \\
\text { or Subcontractor, specify } \\
\text { participation of total contract } \\
\text { amount }\end{array}$ & Percent of Total & Amount \\
\hline
\end{tabular}

\section{Employer's name}

\section{Address}

Telephone number

Fax number

E-mail

\section{Description of Key Activities in Accordance with Criterion 4.2 of Section 3 (Qualification Criteria)}

\section{NOTE}

The Employer should insert here the highly specialized construction activities listed under criterion 4.2 of Section 3 against which the Applicant should demonstrate similarity in the box on the right-hand side. 


\section{B. For Plant - Design, Supply, and Installation Contract}

\section{Form EXP - 1: Experience in Contracts of Similar Size and Nature}

Date:

IFP No.:

OCB No.:

Page

.of

pages

Fill out one (1) form per contract. Each contract shall be supported by documents such as Signed Contract Agreement, Taking-Over Certificate, Contract Completion Certificate or Performance Certificate.

The exchange rate to be used to calculate the value of the contract for conversion to a specific currency shall be the selling rate of the Borrower's Central bank on the date of the contract.

\begin{tabular}{|c|c|c|c|}
\hline \multicolumn{4}{|c|}{ Contract of Similar Size and Nature } \\
\hline Contract No...... of . & \multicolumn{3}{|c|}{ Contract Identification } \\
\hline \multicolumn{2}{|l|}{ Award Date } & \multicolumn{2}{|l|}{ Completion Date } \\
\hline Role in Contract & C Contractor & $\begin{array}{l}\text { Management } \\
\text { Contractor }\end{array}$ & ․ Subcontractor \\
\hline Total Contract Amount & \multicolumn{3}{|l|}{$\$$} \\
\hline $\begin{array}{l}\text { If partner in a Joint Venture } \\
\text { or Subcontractor, specify } \\
\text { participation of total contract } \\
\text { amount }\end{array}$ & Percent of Total & Amount & \\
\hline \multicolumn{4}{|l|}{$\begin{array}{l}\text { Employer's name } \\
\text { Address } \\
\text { Telephone number } \\
\text { Fax number } \\
\text { E-mail }\end{array}$} \\
\hline \multicolumn{4}{|c|}{ Description of the Similarity in Accordance with Criterion 4.1 of Section 3 (Qualification Criteria) } \\
\hline \multicolumn{4}{|l|}{ NOTE } \\
\hline $\begin{array}{l}\text { The Employer should insert here } \\
\text { contract size, complexity, methods, } \\
\text { technology, or other characteristics } \\
\text { as described in Criterion } 4.1 \\
\text { of Section } 3 \text { against which the } \\
\text { Applicant should demonstrate } \\
\text { similarity in the box on the } \\
\text { right-hand side. }\end{array}$ & & & \\
\hline
\end{tabular}


Form EXP - 2: Experience in Key Activities

Date:

IFP No.:

OCB No.:

Page

.of

pages

Fill out one (1) form per contract. Each contract shall be supported by documents such as Signed Contract Agreement, Taking-Over Certificate or Contract Completion Certificate.

Each Applicant must fill out this form.

If complied by Specialist Subcontractors, each Specialist Subcontractor must fill out this form and provide the Specialist Subcontractor's name:

Specialist Subcontractor:

\section{Contract with Similar Key Activities}

\begin{tabular}{|l|l|}
\hline Contract No...... of ....... & Contract Identification \\
\hline
\end{tabular}

\begin{tabular}{|l|l|l|l|}
\hline \multicolumn{2}{|l|}{ Award Date } & \multicolumn{2}{|l|}{ Completion Date } \\
\hline Role in Contract & $\square$ Contractor & $\begin{array}{l}\text { Management } \\
\text { Contractor }\end{array}$ & $\square \quad$ Subcontractor \\
\hline Total Contract Amount & $\$$ & Amount \\
\hline $\begin{array}{l}\text { If partner in a Joint Venture or } \\
\text { Subcontractor, specify participation } \\
\text { of total contract amount }\end{array}$ & Percent of Total & Amployer's name \\
\hline $\begin{array}{l}\text { Address Telephone } \\
\text { number Fax } \\
\text { number }\end{array}$ & \begin{tabular}{l} 
E-mail \\
\hline
\end{tabular} &
\end{tabular}

Description of Key Activities in Accordance with Criterion 4.2 of Section 3 (Qualification Criteria)

\section{NOTE}

The Employer should insert here Criterion 4.2 of Section 3 against which the Applicant should demonstrate similarity in the box on the right-hand side.

Operational certificate from end user specifying hours/years of successful operation of the plant and/or its component, type test report and other requirement as stipulated in Criterion 4.2 of Section 3 should be provided as attachments of this form. 
Form EXP - 3: Specific Experience in Managing Environmental, Health and Safety Aspects

Fill out one form per contract.

Each Applicant must fill out this form.

In case of a Joint Venture, each Joint Venture Partner must fill out this form separately and provide the Joint Venture Partner's name:

Joint Venture Partner:

1. Key Requirement no 1 in accordance with Criterion 4.3 of Section 3:

\begin{tabular}{|l|l|l|l|l|}
\hline Contract Identification & \multicolumn{3}{|l|}{} \\
\hline Award date & \multicolumn{3}{|l|}{} \\
\hline Completion date & $\begin{array}{c}\text { Prime } \\
\text { Contractor } \\
\text { Role in Contract }\end{array}$ & $\begin{array}{c}\text { Member in } \\
\text { JV } \\
\text { 口 }\end{array}$ & $\begin{array}{c}\text { Management } \\
\text { Contractor } \\
\text { 口 }\end{array}$ & $\begin{array}{c}\text { Subcontractor } \\
\square\end{array}$ \\
\hline Total Contract Amount & & & US\$ \\
\hline Details of relevant experience & & & \\
\hline
\end{tabular}

2. Key Requirement no 2 in accordance with Criterion 4.3 of Section 3:

3. Key Requirement no 3 in accordance with Criterion 4.3 of Section 3: 


\section{Form EXP - 4: Environmental, Health and Safety Certification}

Please provide the following information:

Availability of the following valid ISO certification or internationally-recognized equivalent (equivalency to be demonstrated by the Applicant), and applicable to the worksite:

[Select the required certifications from below ${ }^{a}$ ]

- Quality management certificate ISO 9001

- Environmental management certificate ISO 14001

- Health and Safety management certificate ISO 45001

a Depending on the environmental, health and safety issues of the worksite and the type of competition planned (national or international), the list of required certifications may be restricted to those corresponding to the main issue of the worksite management, or removed altogether.

\section{Form EXP - 5: Environmental, Health and Safety Documentation}

Please provide the following information:

Availability of in-house policies and procedures acceptable to the Employer for EHS management:

1. Existence of an Ethics Charter.

2. Existence of a system for monitoring compliance with EHS commitments for the Applicant's Subcontractors and all its partners.

3. Existence of official company procedures for the management of the following relevant points:

[Select 3-5 that apply for the worksite from below options- as per Section 2]

- EHS resources and facilities and EHS monitoring system;

- Project Areas management information (base camps, quarries, burrow pits, storage areas);

- Health and Safety on worksites policy and related guidance;

- Local recruitment and EHS trainings of local staff/subcontractors/local partners;

- Community stakeholder engagement practice;

- Traffic management practice;

- Hazardous products management practice;

- Waste management practice;

- Protection of water resources;

- Biodiversity protection practices;

- Site rehabilitation and revegetation practice;

- Local cultural heritage protection practice;

- Erosion and sedimentation practices;

- Control of infectious and communicable diseases (HIV/AIDS, malaria, COVID-19 etc)

\section{Form EXP - 6: Environmental, Health and Safety Dedicated Personnel}

Please provide CV of the in-house personnel of the main contractor/Joint Venture partners for the EHS positions as follows:

[For Example]

- Environmental Specialist

- Health and Safety Specialist 


\section{Section 5: Eligible Countries}

This section contains the list of eligible countries. Please choose one of the following cases and follow the instructions as appropriate.

\section{NOTES}

For Contracts to be financed by loans/grants from

1. OCR without cofinancing resources:

Unless a waiver of $A D B$ member procurement eligibility restrictions was approved by the ADB Board of Directors, please insert the most recent list of $A D B$ members obtainable from www.adb.org/about/members

EXCEPTION: If any other contract under the project is financed by cofinancing resources that are administered by ADB (other than those listed in para. 2 below), then please state "No nationality restrictions apply, other than any restrictions arising from ITB 4.7."

2. Regular loan from OCR with cofinancing resources from any one of the following funds:

(i) Asian Clean Energy Fund,

(ii) Japan Fund for Poverty Reduction,

(iii) Investment Climate Facilitation Fund,

(iv) Japan Fund for the Joint Credit Mechanism, and

(v) e-Asia and Knowledge Partnership Fund,

Unless a waiver of $A D B$ member procurement eligibility restrictions was approved by the ADB Board of Directors, please insert the most recent list of $A D B$ members obtainable from www.adb.org/about/members

3. Concessional loan from $O C R$ with cofinancing resources from any one of the following funds:

(i) Asian Clean Energy Fund,

(ii) Japan Fund for Poverty Reduction,

(iii) Japan Fund for Public Policy Training,

(iv) Japan Fund for Information and Communication Technology,

(v) Investment Climate Facilitation Fund, and

(vi) e-Asia and Knowledge Partnership Fund,

Unless a waiver of $A D B$ member procurement eligibility restrictions was approved by the $A D B$ Board of Directors, please insert the most recent list of $A D B$ members obtainable from www.adb.org/about/members

4. Regular loan from OCR with cofinancing resources other than those listed in para. 2 above:

Please state "No nationality restrictions apply, other than any restrictions arising from ITB 4.7."

5. Concessional loan from OCR with cofinancing resources other than those listed in para. 3 above:

Please state "No nationality restrictions apply, other than any restrictions arising from ITB 4.7."

6. ADF without cofinancing resources:

Unless a waiver of $A D B$ member procurement eligibility restrictions was approved by the $A D B$ Board of Directors, please insert the most recent list of $A D B$ developed members that have contributed to $A D F$ resources, and all $A D B$ developing members.

EXCEPTION: If any other contract under the project is financed by cofinancing resources that are administered by ADB (other than those listed in para. 7 below), then please state "No nationality restrictions apply, other than any restrictions arising from ITB 4.7." 
7. ADF with cofinancing resources from any one of the following funds:

(i) Asian Clean Energy Fund,

(ii) Japan Fund for Poverty Reduction,

(iii) Japan Fund for Public Policy Training,

(iv) Japan Fund for Information and Communication Technology,

(v) Investment Climate Facilitation Fund, and

(vi) e-Asia and Knowledge Partnership Fund,

Unless a waiver of $A D B$ member procurement eligibility restrictions was approved by the ADB Board of Directors, please insert the most recent list of $A D B$ developed members that have contributed to ADF resources, and all $A D B$ developing members.

8. ADF with cofinancing resources other than those listed in para. 7 above:

Please state "No nationality restrictions apply, other than any restrictions arising from ITB 4.7." 


\section{Section 6: Scope of Contract}

Section 6 (Scope of Contract) (SOC) shall provide sufficient information to enable Applicants to understand clearly the project to be implemented, form the group to perform the contract, and efficiently and accurately prepare Applications that are realistic and competitive. The Employer prepares the SOC that shall become part of the ensuing contract to be awarded.

The SOC should be complete, precise, and clear in order to avoid unnecessary requests for clarification from Applicants that may cause delays in the prequalification process. Depending on the nature of clarifications, the Employer may need to amend the Prequalification Document and eventually extend the deadline for submission of Applications.

The Employer shall assign appropriate, competent, and experienced staff to prepare the SOC such that the widest possible competition is permitted, while at the same time clearly specifying the required standards of field organization and personnel, equipment, methods, workmanship, and implementation schedule. A well prepared SOC ensures that a particular open competitive bidding (OCB) procedure shall meet the objectives of economy, efficiency, fairness, and transparency.

\section{Table of Contents}

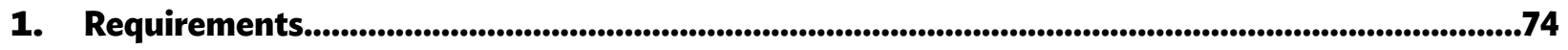

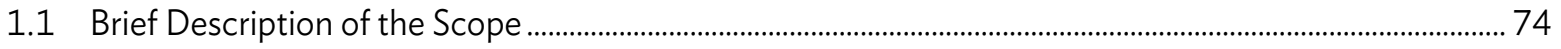

1.2 Major Contract Components ................................................................................................................................... 74

1.3 Estimated Quantities of Major Components .............................................................................................. 74

1.4 Methods Required .............................................................................................................................................. 74

1.5 Key Personnel and Key Equipment.................................................................................................................. 74

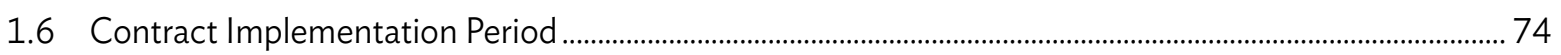

1.7 Environmental, Health and Safety Management Requirement ................................................................ 74

2. Supplementary Information .................................................................................................................................76

2.1 Project Country ........................................................................................................................................ 76

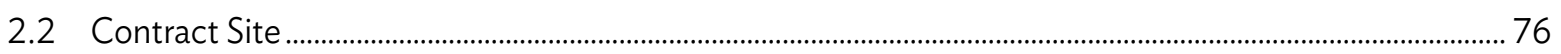

2.3 Applicable Conditions of Contract ...................................................................................................................... 76

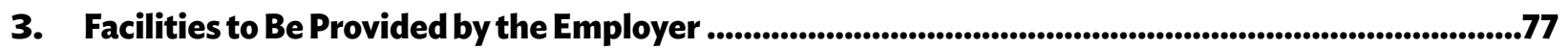




\section{Requirements}

\subsection{Brief Description of the Scope}

\subsection{Major Contract Components}

\section{NOTE}

This document should be a skeleton of the Future Functional Specifications and should outline the main components of the project including the major expected technical characteristics and performance requirements of the Plant including but not limited to the capacity of the plant (MVA, MW, etc.) the expected performance and efficiency of the plant, the applicable standards, etc.

\subsection{Estimated Quantities of Major Components}

\subsection{Methods Required}

\subsection{Key Personnel and Key Equipment}

\section{NOTE}

The Employer should insert the followingstatement: "The Bidder's capacity to mobilize the key personnel and key equipment for the Contract consistent with its proposal regarding work methods, scheduling, and material sourcing in sufficient detail and fully in accordance with the requirements that will be stipulated in the Bidding Document will be assessed prior to the award of the Contract to the successful Bidder."

\subsection{Contract Implementation Period}

\subsection{Environmental, Health and Safety Management Requirement}

\section{NOTE}

The Employer's team preparing the EHS requirements should include a suitably qualified Environmental, Health and Safety specialist/s as determined by the EMP. The Employer should attach or refer to the Employer's environmental, health and safety policies that will apply to the project if available.

Based on the EIA undertaken for the project and this specific contract, the Employer shall provide key EHS risks and impacts and expectations on contractors to manage the risks and impacts. This may include as appropriate, but not limited to a summary of: key expectations in managing labor and working conditions, protection of the environment, health and safety and security of the site, community health and safety, management of safety of hazardous materials, resource efficiency and pollution prevention and management, biodiversity conservation and sustainable management of living natural resources etc. Any summary (key) information provided here shall not be inconsistent with the more detailed requirements in the bidding document. 
The Employer should highlight the requirement of a Site Specific Environmental/ Health and Safety Management Plan (SSEHSMP) to be prepared based on the outline Environmental Health and Safety Management Plan (EHSMP) submitted as part of the Contractor's technical proposal. The SSEHSMP shall be submitted within the contractual timeline (e.g. 28 days) outlined in the Contract Conditions. The Engineer/Project Manager shall endeavor to issue no-objection of the SSEHSMP within a prescribed period (e.g.10 days) upon receipt of the SSESHMP, if the EHS requirements for the plan is met. No physical works shall commence on site prior to the confirmation of no objection of the SSEHSMP has been obtained from the Engineer as per Contract Conditions.

\section{Minimum Content of Requirements}

In preparing detailed specifications for requirements, the specialists should refer to and consider:

- $\quad$ project reports e.g. EIA/EMP

- consent/permit conditions

- required standards including ADB Safeguard Policy Statement and related EHS Guidelines

- relevant international conventions or treaties etc., national legal and/or regulatory requirements and standards (where these represent higher standards than the ADB Guidelines)

- $\quad$ relevant international standards e.g. WHO Guidelines for Safe Use of Pesticides

- relevant sector standards e.g. EU Council Directive 91/271/EEC Concerning Urban Waste Water Treatment

- grievance redress mechanism including types of grievances to be recorded and how to protect confidentiality

The detail specification for EHS should, to the extent possible, describe the intended outcome rather than the method of working.

The EHS requirements should be prepared in manner that does not conflict with the relevant General Conditions of Contract (and the corresponding Particular Conditions if any) and other parts of the specifications.

\section{Payment for EHS Requirements}

The Employer's environmental, health and safety, and procurement specialists should consider how the Contractor will cost the delivery of these requirements. In the majority of cases, the payment for the delivery of these requirements shall be a subsidiary obligation of the Contractor covered under the prices quoted for other Bill of Quantity items. For example, normally the cost of implementing work place safe systems of work, including the measures necessary for ensuring traffic and road safety, shall be covered by the Bidder's rates for the relevant works. Alternatively, provisional sums could be set aside for discrete activities for example to encourage the contractor to deliver additional environmental, health and safety outcomes beyond the requirement of the Contract. 


\section{Supplementary Information}

\subsection{Project Country}

\subsection{Contract Site}

\subsection{Applicable Conditions of Contract}

\section{NOTE}

The Employer should indicate which particular conditions of contract will be applied during the execution of the Contract (i.e., FIDIC Conditions of Contract for Construction Multilateral Development Bank Harmonized Edition General Conditions June 2010 [for civil works contract]; Form of Contract for Plant - Design, Supply, and Installation or Form of International Contract for Process Plant Construction published by the Engineering Advancement Association of Japan [for plant contract]; or other internationally recognized standard conditions of contract and contract forms acceptable to $A D B$ ). 


\section{Facilities to Be Provided by the Employer}




\section{Glossary}

Applicant

Bidder

Contractor

Employer

Joint Venture

Management

Contractor

Prequalification

Specialist

Subcontractor

Supplier

Works

Writing
A party that submits an application for prequalification for a particular works contract or plant contract.

A party that submits a bid for a particular works contract or plant contract.

A legal entity that is party to and performs a works contract, the other party to the contract being the "Employer."

One of the two parties to a works contract, the other party being the "Contractor."

An ad hoc association of firms that pool their resources and skills to undertake a large or complex contract in the role of the contractor, with all firms (partners in the Joint Venture) being legally liable, jointly and severally, for the execution of the contract in the event of a partner's withdrawal.

A firm, acting in the role of the contractor, that does not normally perform contract construction work directly, but manages the work of other (sub)contractors, while bearing full responsibility and risk for price, quality, and timely performance of the works contract.

An assessment made by the Employer of the appropriate level of experience and capacity of firms expressing interest in undertaking a particular contract before inviting them to bid.

A specialist enterprise engaged for highly specialized processes which cannot be provided by the main contractor.

An entity or company from which the equipment and materials to be used for a contract (works contract or plant contract) is purchased or obtained by the bidder.

The total work involvement in a construction contract, including the permanent works or finished product as specified, and the temporary works required by the contractor for the execution and completion of the contract.

For the purpose of this document, any authenticated handwritten, typed, or printed communication, including telex, cable, e-mail, any electronic form, and facsimile transmission, with proof of receipt when and in the form requested by the sender. 


\section{User Guide for Prequalification of Bidders \\ Standard Bidding Document}

This User's Guide is intended to provide guidance to borrowers on how to prepare a prequalification document based on the Asian Development Bank's Standard Bidding Document for the Prequalification of Bidders. It also provides guidance on how to evaluate applications. It is applicable to projects governed by the Procurement Regulations for ADB Borrowers: Goods, Works, Nonconsulting and Consulting Services (2017, as amended from time to time).

\section{About the Asian Development Bank}

ADB is committed to achieving a prosperous, inclusive, resilient, and sustainable Asia and the Pacific, while sustaining its efforts to eradicate extreme poverty. Established in 1966, it is owned by 68 members -49 from the region. Its main instruments for helping its developing members are policy dialogue, loans, equity investments, guarantees, grants, and technical assistance. 